\title{
e-Devlet Kapsamında Kurumsal Bilgi Sistemlerinin Değerlendirilmesi: İçişleri Bakanlığı Örneği*
}

\author{
The Evaluation of Enterprise Information Systems within the \\ Scope of e-Government: A Case of the Ministry of Internal Affairs
}

\author{
Şahika EROĞLU** ve Özgür KÜLCÜ***
}

\begin{abstract}
Öz
Kurumsal bilgi sistemleri, kurumun hizmet verdiği iç ve dış müşterilerin beklentileri ile yasal ve idariyükümlülükleriçerçevesinde yapılandırılmakta ve temel olarak belgeyönetimi programlarına dayanmaktadır. Belge yönetimi programları geliştirilirken kurumsal yapı ve işleyiş, yazılım ve donanım mimarisi, yasal ve idari düzenlemeler göz önünde bulundurulmak durumundadır. Belge yönetimi kapsamında değerlendirilen kurumsal bilgi sistemleri e-devlet uygulamalarının da omurgasını oluşturmaktadır. Çalışmada bu çerçevede belge yönetimi, kurumsal bilgi sistemleri ve e-devlete ilişkin literatür incelenmiş, araştırma alanını oluşturan Içişleri Bakanlığında bilgi sistemleri, belge yönetimi uygulamaları ve e-içişleri sistemi analiz edilmiştir. Bu çerçevede ulusal ve uluslararası koşullar, standartlar, idari ve yasal düzenlemeler çerçevesinde geliştirilen anket, Içişleri Bakanlığı Merkez Teşkilatı, 81 ilin valilikleri, bunlara bağlı kaymakamlık teşkilatları ile il özel idarelerinde görevli 500 e-devlet proje sorumlusuna gönderilmiş olup geri dönüş yapılan 491 anket değerlendirmeye alınmıştır. Çalışma sonuçlarında e-içişleri sisteminin geliştirilmesi gereken yönleri ortaya konmuş; konuyla ilgili önerilere yer verilmiştir.
\end{abstract}

Anahtar sözcükler: e-Devlet, e-içişleri, Kurumsal bilgi sistemleri, Içişleri Bakanlığı

Abstract

Enterprise information systems are to be restructured within the frame of new approaches, the expectations of inner and outer customers to whom the organizations offer service, legal and administrative obligations and they included within the basic components of enterprise information systems. While developing records management programs, the enterprise structure and workflow, software and hardware architecture, legal and administrative obligations which influence the current information management applications have to be taken into consideration. Enterprise information systems considered within the scope of records management comprise of the backbone belonging to the e-government applications. Accordingly, the records management

* Bu makale Hacettepe Üniversitesi Bilgi ve Belge Yönetimi Bölümünde hazırlanan "e-Devlet Kapsamında Kurumsal Bilgi Sistemlerinin Değerlendirilmesi: İçişleri Bakanlığı Örneği" başlıklı yüksek lisans tezine dayanılarak hazırlanmıştır.

** Arş. Gör., Hacettepe Üniversitesi, Bilgi ve Belge Yönetimi Bölümü. (sahikaeroglu@hacettepe.edu.tr)

*** Doç.Dr., Hacettepe Üniversitesi, Bilgi ve Belge Yönetimi Bölümü. (kulcu@hacettepe.edu.tr) 
programs and literature related to e-government are examined within this study and information systems, records management applications and e-içişleri systems which comprise of the research field are analyzed. The survey is developed in accordance with national and international conditions, standards, legal and administrative arrangements. 500 surveys are sent to the Ministry of Internal Affairs, Central Organization, governorships of 81 cities, related district governorships and special provincial directorate of administrations; 491 of them are returned and evaluated. As a conclusion the developments of e-Interior system have been revealed and recommendations are given on the subject.

Keywords: e-Government, e-Interior, Enterprise information systems, Ministry of Internal Affairs

\section{Giriş}

Bilişim teknolojileri pek çok alanda olduğu gibi kamu hizmetlerinin yapılandırılmasında ve vatandaş devlet ilişkilerinde de çeşitli değişimlere yol açmaktadır. Bu süreçte kamusal hizmetlerin daha hızlı, şeffaf ve mekân engeli olmadan gerçekleştirildiği e-devlet uygulamaları giderek yaygınlaşmaktadır. e-Devlet, vatandaş ilişkilerinin yeniden yapılanmasına ve iş süreçlerinin mesai kavramının ötesinde zaman ve mekândan bağımsız yürütülebilmesine olanak sağlamaktadır (Özbek, 2007, s. 2). Kurumsal bilgi sistemleri e-devlet uygulamalarında en önemli yapılardan biridir. Kurum içi ve dışı iletişimin sağlanmasında, iş süreçlerinin yürütülmesinde, yönetim ve karar verme süreci için gerekli bilginin sağlanmasında, önceden yapılandırılmış işlerin yasal ve idari yükümlülükler çerçevesinde gerçekleştirilmesinde kurumsal bilgi sistemleri vazgeçilmez bir öneme sahiptir. Kurumsal bilgi sistemleri, yeni yaklaşımlar, kurumun hizmet verdiği iç ve dış müşterilerin beklentileri ile yasal ve idari yükümlülükler çerçevesinde yapılandırılmak durumundadır. İyi bir kurumsal bilgi yönetimi sisteminin temelde iyi bir belge yönetimi sistemine dayandığından söz edilmektedir (Sprehe, 2005, s. 298). Giderek basılı ortamın yerini alan elektronik belge yönetimi uygulamaları ile belge yönetimi, basılı üretilmiş belgelerin elektronik kopyaları ile elektronik ortamda üretilmiş belgelerin yönetimini kapsayacak biçimde genişlemektedir. Uygulamadaki örneklerinde çoğunlukla "Doküman Yönetim Sistemi", "Evrak Yönetim Sistemi" gibi isimlerle adlandırılan elektronik belge yönetim sistemleri elektronik dokümanların ve dosyaların üretimi, e-posta yönetimi, tarama ve erişim, iş akışı entegrasyonu, kullanıcı ara yüzleri, mobil çalışma ortamları ve uzaktan erişim vb. alanları kapsamaktadır (Azad, 2008 , s. 22). Kurumsal fonksiyonlar yerine getirilirken üretilen belgeler, kurumların sahip oldukları bilginin kaynağını oluşturmaktadır. Kurumsal iletişimi ve haberleşmeyi sağlamak, neyin, nerede, nasıl ve kim tarafından yapılmış olduğunu bilmek, başarılardan ve başarısızlıklardan ders çıkarmak ve mevcut bilgilerden faydalanmak, belge yönetiminin en temel hedefleri arasındadır (Özdemirci, 2008, s. 225; Yıldız, 2005, s. 23).

Çalışmada, genel olarak teknolojinin gelişmesi ve özellikle internetin günlük hayatın vazgeçilmez bir parçası haline gelmesiyle yaygınlaşan e-devlet uygulamalarında son yıllarda yaşanan hızlı gelişmeler göz önünde bulundurularak, kurumsal iş süreçleri ve iletişim için oluşturulan ve kullanılan kurumsal bilgi sistemlerinin analizi amaçlanmıştır. 
Bu çerçevede, İçişleri Bakanlığında e-içişleri örneğinde kurumsal bilgi sisteminin değerlendirilmesinde yararlanılmak üzere, e-içişleri sistem gereksinimlerini analiz etmek üzere geliştirilen anket üzerinden, kurumda var olan koşulları, eksikliklerini saptamak ve yaşanan sorunların çözümünde yararlanılabilecek önerileri sıralamak hedeflenmiştir.

\section{Kurumsal Bilgi Sistemleri ve e-Devlet Uygulamaları}

Kurumsal bilgi yönetimi ile kurumlarda iş süreçlerinin daha etkin kılınması amaçlanmaktadır. Bu çerçevede farklı bilgi sistemleri kullanılarak gerçekleştirilen kurumsal iletişim kanallarının ve çalışmalar için gerekli bilgi akışının sağlanacağı platformların belirlenmesi gerekmektedir (Yao, Kam ve Chan, 2007, s. 53). Kurumsal bilgi sadece yöneticilerin ve belirli alanlardaki uzmanların sahip olduğu örtük bilgi (tacit information) değildir. Günümüzde kurumsal iş süreçlerinin her aşamasının kayıtlı hale getirilmesi, bu çerçevede görev tanımlarının yapılması ve iş süreçlerinin tutulan kayıtlara göre sürdürülmesi önemli beklentiler arasında yer almaktadır. Bu koşullarda açık bilgi (explicit information) ve yapılandırılmış bilgi sistemleri daha ön plana çıkmaktadır. Kurumlarda neredeyse her çalışanın yürüttüğü faaliyetlerde bilgi temel girdi ve çoğu zamanda çeşitli tür rapor ve dokümanlarla çıktı niteliğindedir. Bu çerçevede kurumsal bilgi yönetimi çalışmaları, doğru bilgiyi, doğru yerde ve doğru zamanda insanlara sağlamaya yoğunlaşmaktadır (NHS National Library for Health, 2005, s. 3). Kurumsal bilgi yönetimi sistemlerinin hedefi, kurumsal amaçların etkin biçimde gerçekleştirilebilmesi için bilginin sistematik olarak yönetilmesidir (Barutçugil, 2002, s. 50).

Bilgi ve iletişim teknolojisindeki gelişmeler kurumsal yönetim yapılarında da önemli değişimlere yol açmıştır. Bu süreçten etkilenen kamu kurumlarının idari yapıları ve hizmet yaklaşımlarında önemli dönüşümler yaşanmaktadır. Bu noktada vatandaş merkezli yönetim yaklaşımları, iletişim ve iş süreçlerinin teknolojik olanaklarla zamandan ve mekândan bağımsız yürütülmesine dönük e-devlet uygulamaları ön plana çıkmaktadır. Devlet ile vatandaş, devlet ile çalışanlar arasında bilgi ve iş akışının teknolojik platform ve altyapılar kullanılarak daha hızlı, kesintisiz ve güvenilir bir şekilde yürütülmesi için oluşturulan model olarak tanımlayabildiğimiz e-devlet ayrıca kamu hizmetlerinde yenilikler yapmanın başka bir yolu değil, hizmetleri temelden değiştirecek ölçekte bir dönüşüm yapma olarak algılanmaktadır (Deloitte Research, 2000, s. 4). Öte yandan kavramın, kamu idari birimlerinin enformasyon teknolojilerini kullanarak vatandaşlar, işletmeler ve diğer devlet birimleri arasındaki ilişkilerini dönüştürmesi olarak da nitelendirildiği dikkati çekmektedir (Worldbank, 2012).

Bilgi ve iletişim teknolojisindeki gelişmeler kamu yönetimi unsurlarında da birçok değişim ihtiyacını beraberinde getirmiştir. Teknolojinin devlet hizmetlerinde kullanılmasını ifade eden e-devlet ile hükümetler, daha sağlam alt yapılar kurarak verimli hizmetler sunmayı amaçlamaktadırlar. Vatandaşlar ise ulaşmak istedikleri bilgi veya resmi evraklara daha hızlı ulaşarak devletin karar mekanizmalarında daha aktif olarak yer alma olanağı bulmaktadırlar (Delikurt, 2007, s. 45). 
Genel olarak baktığımızda e-devlet ile temel amaç; her alanda faydalanılan teknolojik gelişmeleri kamusal alanda da çağın getirilerine uygun olarak kullanmaktır. e-Devlet ile devlet hizmetlerinin sunumunda sadece bilgi ve iletişim teknolojilerinin kullanımı değil aynı zamanda kamu hizmeti sunanların, bu hizmetlerden faydalananların dönüşümü ve bu çerçevede süregelen hantal devlet yapısından kurtularak, çağın gereklerine uygun etkileşimli ve yaygın bir hizmet sunumunun sağlanmasının hedeflendiği söylenebilir.

Kamu yönetiminin bilgi sistemleri ile yeniden yapılandırılması, klasik bürokrasinin ötesinde sosyal ve teknolojik gelişmelerle uyumlu kamu idareciliği kavramını ortaya çıkarmıştır (Yıldırım, 2010, s.1330). Kurumsal bilgi sistemleri önceleri özel sektördeki şirketler tarafından uygulanmış ve çok geçmeden kamu yönetiminin gündemine de girmiştir. Kurumlar bu sistemler ile sahip oldukları bilgiyi çeşitli ortamlarda işleyip kullanabilmektedirler. Herhangi bir kurumda üretilen bilginin sayısal hale getirilip bilgisayar ortamında saklanabilmesi, bilgiye zaman ve mekândan bağımsız her ortamda ulaşılması kolaylığını getirmiştir. Bu durum bilgi yönetimine dönük süreçlerin kurumlarda belirli sistem dâhilinde yürütülmesine, dolayısıyla profesyonel anlayışla yönetilmesine yol açmıştır.

Teknolojik olanakların ve internet erişiminin yaygınlaşması kamu kurumlarının daha kolay ve etkin biçimde vatandaş odaklı hizmetler geliştirmesine olanak sağlamaktadır (Horan ve Abhichandani, 2006, s. 33). Bu çerçevede, yapılandırılan e-devlet uygulamalarının önemli bölümü hâlihazırda genel evrak ve arşiv yönetimi kapsamında yer alan belge yönetimi uygulamalarına dayanmaktadır. e-Devlet uygulamalarının omurgasını oluşturan kurumsal bilgi sistemleri, ilk bakışta mevcut teknolojinin kurumsal iş süreçlerine yansıması gibi görünse de özünde daha karmaşık yapıları gerektirmektedir (Kampffmeyer, 2006 , s.8). Kurumsal bilgi sistemleri kurumsal yapı ve işleyiş, yazılım ve donanım mimarisi, yasal ve idari yükümlülükler göz önünde bulundurularak yapılandırılmalıdır (Verdegem ve Verleye, 2009, s.487). Basılı sistemlerde olduğu gibi elektronik sistemlerde de iş süreçlerinin etkinliğinden güvenliğine kadar pek çok unsur göz önüne alınmalıdır. Ayrıca elektronik ortamda belgelerin özgünlüğü, güvenilirliği ve bütünlüğüne dönük koşullar karşılanmadan belge yönetimi uygulamalarının elektronik ortamda yürütülmesi bazı sorunlara neden olmaktadır (Mokhtar ve Yusof, 2009, s.233). Yine bilgi paylaşımının tek bir platformda erişimini temel alan e-devlet uygulamalarıyla birlikte mahremiyet, gizlilik, farklı sistemlerin bütünleşik çalışmalarına yönelik standartlaşma gereksinimlerinin karşılanması gerekmektedir (Fedorowicz, Gogan ve Culnan, 2010, s. 315).

Türkiye'de de özellikle 1990'lı yıllarla birlikte kurumlarda başlayan otomasyon uygulamaları çerçevesinde bilgi sistemlerinde elektronik uygulamalar başlamıştır. Bu çerçevede, kurum kütüphanelerinin bibliyografik künyelerinin elektronik ortama taşınması, idari ve mali iş süreçlerinde kullanılan yönetim bilgi sistemleri belli başlı otomasyon uygulamaları arasında yer almıştır. 2000'li yıllarla birlikte dünyadaki 
örneklerine paralel olarak tam metin bilgi sistemleri ve bütünleşik içerik yönetimi uygulamaları kullanılmaya başlanmıştır. Ancak Türkiye'de elektronik belge yönetimi uygulamaları, donanım alt yapısının geliştirilmesi ve e-imza gibi bir dizi güvenlik koşuluna dönük yasal ve idari düzenlemelerin yapılandırılmasını gerektirdiğinden, uluslararası uygulama örneklerine göre gecikmeli başlamıştır (Cimtech Ltd, 2009, s. 10-12; Herrera-Viedma ve Peis, 2003, s. 234-238; Kampffmeyer, 2006, s. 3). Türkiye'de özellikle 2004 yılında yürürlüğe giren Elektronik İmza Kanunu ile birlikte (Elektronik İmza Kanunu, 2004) gerek kamu gerekse özel sektör yoğun biçimde elektronik bilgi ve belge yönetim uygulamalarına geçmeye yönelmiştir (Külcü, 2010).

\section{e-Devlet Uygulamalarının Bir Parçası Olarak: e-i̇çişleri Projesi}

İlk olarak özel sektördeki şirketler tarafından uygulanan ve akabinde kamu sektöründe de kullanılmaya başlanan kurumsal bilgi sistemleri, e-devlet ve e-dönüşümün bir gereği olarak yeni kamu yönetimi yaklaşımında yerini almıştır. Ülkemizde e-Devlet ve kurumsal bilgi sistemlerinin öncü uygulayıcılarından olan İçişleri Bakanlığı da, e-devlet uygulamaları kapsamında bilgi ve belge yönetimi süreçlerini elektronik platformda çeşitli politikalar ve güvenlik süreçleriyle kurumsal bilgi sistemi üzerinden yürütmektedir. Bu sistem dâhilinde elektronik posta sistemi, elektronik belge yönetimi sistemi, kurumsal iletişim sistemleri yer almaktadır. Kurumda kullanılan "e-i̇çişleri Bilgi Sistemi" kurumsal içerik uygulamalarına yönelik ihtiyaçları karşılamak amacıyla geliştirilmiştir. Bu kapsamda yapılandırılmış kurum bilgi sistemi iki bileşenle hizmet vermektedir. Bunlar kurum resmi web sayfası ve kurumsal bilgi yönetimi işlemlerinin yürütüldüğü e-içişleri platformudur.

e-İçişleri Projesi Iç̧işleri Bakanlığı merkez birimlerinin, bütün valilikler, kaymakamlıklar ve il özel idarelerinin yürütmüş olduğu iş ve işlemlerinin elektronik ortamda yapılmasını sağlamak üzere başlatılmış bir e-dönüşüm projesidir. Bu proje ile İçişleri Bakanlığına ait bazı hizmet ve uygulamalar internet üzerinden yapılmaktadır. e-Dönüşüm Türkiye faaliyetleri kapsamında, Iç̧işleri Bakanlığına düşen görevin önemli bir parçasını oluşturan proje ile daha hızlı ve sağlıklı hizmet verilebilmekte; ayrıca maliyet ve zaman tasarrufu da sağlanmaktadır. e-Içişleri Projesi, 28/07/2006 tarih ve 26242 sayılı Resmi Gazete'de 2006/38 sayılı Yüksek Planlama Kurulu Kararı olarak yayınlanan Bilgi Toplumu Stratejisi ve Eki Eylem Planı dokümanında; "Türkiye'de halen başarıyla uygulanan ve belirli aşamalarda hayata geçirilmiş olmakla birlikte devam eden önemli e-devlet projeleri kapsamında İçişleri Bakanlığı tarafından kurumsal uygulamaların e-dönüşümünün sağlanmasına yönelik e-bakanlık projesi" olarak yer almaktadır. Proje 2006 yılında pilot uygulama ile başlamıştır. 17 Aralık 2009 tarihli Genelge ile 01.01.2010 tarihinden itibaren İçişleri Bakanlığı merkez ve taşra teşkilatında projenin gerçek uygulaması başlatılmış olup halen uzman personel desteğiyle yürütülmektedir. 
e-İçişleri projesi ile:

$\diamond$ Bütün yazışmaların elektronik ortamda yapılması sağlanarak kâğıtsız ofis uygulamasını gerçekleştirmek ve elektronik ortamda kurumsal arşivin oluşmasını sağlamak,

$\diamond$ Önceki yazışmaları elektronik ortama aktararak kolay erişilmesini sağlamak,

$\diamond$ e-içişleri uygulamalarının tüm birimlerde bir otomasyon ile uygulanmasını sağlamak,

$\diamond \quad$ Valilik ve kaymakamlıklarda "Tek Adımda Hizmet Faaliyetleri"nin elektronik ortamda uygulanmasıyla etkinliğini artırmak,

$\diamond$ Vatandaş odaklı hizmetleri maksimum oranda yaygınlaştırmak,

$\diamond$ e-iç̧işleri hizmetlerini mobil ortama da taşıyarak kullanımda yaygınlık ve süreklilik sağlamak,

$\diamond$ Bakanlık merkez ve taşra teşkilatının bilişim altyapısını sürekli güçlü ve güncel tutmak,

$\diamond$ Bakanlığın bilişim altyapısını yedeklemek amaçlanmıştır (Başa, 2012).

İçişleri Bakanlığı Bilgi İşlem Dairesi Başkanlığı tarafından yürütülmekte olan e-iç̧işleri Projesinin en önemli parçası olan doküman yönetim sistemine e-imza entegrasyonu tamamlandıktan sonra, 5070 sayılı Kanunda belirtildiği üzere ıslak imza ile aynı hukuki dayanağı olan e-imza ile imzalanan evrakların ayrıca ıslak imzayla imzalanmasına gerek kalmamış, birimler arasında kâğıtsız ofis uygulamasına geçildiğinden kağıt, posta, toner, yazıcı gibi masraflardan büyük oranda tasarruf sağlanması amaçlanmıştır. Genel yapı olarak birim bazındaki modülleri içeren bir proje olan e-içişleri projesi, değişen mevzuat ve gereksinimler çerçevesinde güncellenebilmektedir. Proje kapsamında kurumsal iş süreçlerinde kullanılan en önemli modüllerden biri de Doküman Yönetim Sistemi'dir. e-Posta yönetim sistemleri ve diğer kurum içi bilgi sistemleriyle bağlantılı olarak çalışan bu modül ile resmi iş ve işlemler ve yazışmalar yürütülmektedir. Proje ile ayrıca son dönemlerde literatürde üzerinde durulan önemli bir konu olan kâğıtsız ofis uygulaması doğrultusunda İçişleri Bakanlığı Merkez ve Taşra Teşkilatı dâhilinde belge yönetim süreçleri Şekil 1'de gösterilen yaşam döngüsü çerçevesinde gerçekleştirilmektedir.

İçişleri Bakanlığı Merkez ve Taşra Teşkilatı belge yönetim sürecleri yaşam döngüsüne göre Döküman Yönetim Sisteminde e-içişleri projesi kullanıcıları tarafından kullanılan evrakların sisteme eklenmesi, havalesi, havale edilen evrakların takibi, kâğıt ortamındaki evrakların taratılması, evrakların haklar ve yetkiler çerçevesinde aranması, evrakların sistematik olarak elektronik ortamda saklanması ve yönetilmesi gibi işlevler gerçekleştirilmektedir. Modül, kaynak tasarrufunun yanı sıra daha önce uzun zaman alan toplu imzalama süreçleri yerine e-imzanın kullanılmasıyla zaman tasarrufu da sağlamaktadır. Daha önceleri basılı ortamda yapılan birçok işlem bu sistemle birlikte aşamalı olarak büyük oranda elektronik ortama geçirilmiştir. Proje başlangıç tarihi olan 
2006 yılından bu yana sistem arşivinde toplam 45 milyon evrak elektronik ortamda kayıt altına alınmıştır. e-iç̧işleri projesi sayesinde kağıt, zarf, toner, postalama maliyetlerinden yıllık 20 Milyon TL tasarruf edilebildiği tahmin edilmektedir (İçişleri Bakanlığı Bilgi İşlem Dairesi Başkanlığı, 2012).

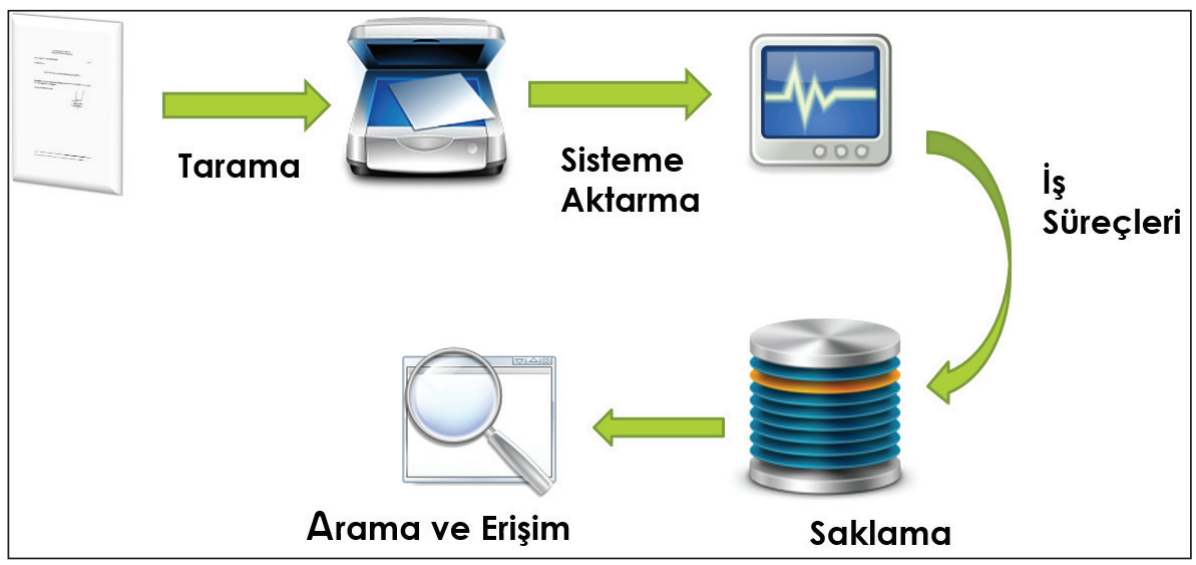

Şekil 1. Doküman Yönetim Sistemi İş Akışı

\section{Yöntem}

Çalışmanın evrenini e-devlet kapsamında kurumsal bilgi sistemleri ve elektronik belge yönetimi uygulamalarının, konuya ilişkin ulusal ve uluslararası standartlar ve düzenlemeler çerçevesinde İçişleri Bakanlığında incelenmesi oluşturmaktadır. Kuramsal bölümde ele alınan konulara ilişkin alan çalışmaları, İçişleri Bakanlığında gerçekleştirilmiştir. İçişleri Bakanlığında kurum içi bilgi sistemleri ve elektronik belge yönetimi uygulamaları "e-İçişleri" adlı platform üzerinden yürütülmektedir. Platformu İçişleri Bakanlığına bağlı merkez birimleri ile taşra teşkilatı, elektronik ortamda yürüttükleri iş ve işlemlerle bilgi paylaşımı amacıyla kullanmaktadırlar. Çalışmada gerçekleştirilen anket İçişleri Bakanlığı merkez ve taşra teşkilatlarında e-içişlerine erişim yetkisi olan toplam 500 e-içişleri proje sorumlusuna gönderilmiş ve geri dönüş sağlanan 491 anket formu değerlendirmeye alınmıştır. Anketin yanıtlanma oranı \%98,2'dir. e-Devlet uygulamalarına geçiş yapan ilk kurumlardan olan İçişleri Bakanlığının (Özata ve Sevinç, 2010, s. 134) çalışma alanı ve kapsamının genişliği göz önüne alınarak örneklem olarak seçilmiştir.

Çalışmada kullanılan anket, geliştirilen web tabanlı bir platform aracılığıyla dağıtılmıştır. Anket çalışmasının değerlendirilmesinde PASW (Predictive Analytics SoftWare) programından yararlanılarak 39 değişken üzerinde analizler gerçekleştirilmiştir. PASW güvenilirlik analizine göre anket çalışmasının içsel tutarlılığına yönelik güvenilirlik derecesi Crombach Alpha değeri ölçülmüştür (Özdamar, 2004, s. 633). 
Araştırmada Crombach Alpha değeri demografik değişkenler çıktıktan sonra 0,95 olarak elde edilmiş ve bu oran da anketin yüksek güvenilirlik derecesinde olduğunu ortaya koymuştur. Eğilim belirlemeye dönük sorular, anket deneklerinin çalışma pozisyonuna göre çapraz tablolarda sunulmuştur. Bu tabloların değerlendirilmesinde Ki Kare testinden faydalanılmıştır. Bulguların analizinde verilerin toplanması ve elde edilen sonucun toplam birim sayısına bölünmesi ile elde edilen aritmetik ortalama değeri de kullanılmıştır. Ayrıca verilerin tutarlıı̆ının saptanabilmesi için ilgili tablolara ilişkin standart sapma değerleri hesaplanmıştır (Baş, 2010, s. 112-113).

\section{Bulgular ve Değerlendirme}

Ankete katılan 491 katılımcıya ait demografik bilgiler sunulmaktadır. Tablolarda oranlar grupların toplam denek sayıları (Yönetici: 99, Uzman: 187, İdari: 135, Teknik: 70, Toplam: 491) göz önüne alınarak hesaplanmıştır.

Katılımcıların kurumda toplam çalışma sürelerine göre dağılımı: Yapılan anket çalışmasında katılımcıların kurumdaki çalışma sürelerine ait bulgular elde edilmiştir. Anketi yanıtlayan katılımcıların çoğunluğu (\%30-150 kişi) kurumda bir ile iki yıl arasında görev yapmaktadır. Daha sonra ikinci sırada (\%20-97 kişi) kurumda yirmi bir yıl ve üzerinde görev yaptıklarını bildirmişlerdir. Kurumda üç ile beş yıl arasında görev yapanlar (\%18,3-90 kişi ) üçüncü sırada bulunmaktadır. Altı ile on yıl arasında görev yapanlar ise 89 kişidir $(\% 18,1)$.

Katılımcıların kurumdaki pozisyonlarına göre dağılımı: Ankete yanıt veren katılımcıların çoğunluğu \%38 (187 kişi) ile uzman personel iken, \%27,5 idari personel (135 kişi), \%20 yönetici (99 kişi) ve 14,3'ü (70 kişi) teknik personelden oluşmaktadır.

Tablo I. Kurum İçi İş Süreçlerinin Yerine Getirilmesinde Elektronik Evrak ve Belge Sisteminin Yeterliliği

\begin{tabular}{|c|c|c|c|c|c|c|c|c|}
\hline & & 1 & 2 & 3 & 4 & 5 & $\bar{x}$ & $\sigma$ \\
\hline \multirow[t]{2}{*}{ Yönetici } & & 2 & 21 & 9 & 59 & 8 & 3,50 & 0,98 \\
\hline & $\%$ & 2,0 & 21,2 & 9,1 & 59,6 & 8,1 & & \\
\hline \multirow[t]{2}{*}{ Uzman } & & 11 & 18 & 18 & 112 & 28 & 3,68 & 1,03 \\
\hline & $\%$ & 5,9 & 9,6 & 9,6 & 59,9 & 15,0 & & \\
\hline \multirow[t]{2}{*}{ İdari personel } & & 5 & 12 & 14 & 83 & 21 & 3,76 & 0,94 \\
\hline & $\%$ & 3,7 & 8,9 & 10,4 & 61,5 & 15,6 & & \\
\hline \multirow[t]{2}{*}{ Teknik personel } & & 2 & 9 & 5 & 46 & 8 & 3,70 & 0,94 \\
\hline & $\%$ & 2,9 & 12,9 & 7,1 & 65,7 & 11,4 & & \\
\hline \multirow[t]{2}{*}{ Toplam } & & 20 & 60 & 46 & 300 & 65 & & \\
\hline & $\%$ & 4,1 & 12,2 & 9,4 & 61,1 & 13,2 & & \\
\hline
\end{tabular}

1. Bütünüyle olumsuz; 2. Olumsuz; 3. Kararsız; 4. Olumlu; 5. Bütünüyle olumlu 
Katılımcıların eğitim düzeyine göre dağılımı: Anket kapsamında katılımcıların eğitim düzeylerine yönelik bulgular elde edilmiştir. Katılımcıların çoğunun \%48,3 (237 kişi) lisans eğitimi aldığı anlaşılmaktadır. Ön lisans eğitimi alan kullanıcılar \%30,5 ile (150 kişi) ikinci sırada yer alırken katılımcıların 18'i $(\% 3,7)$ yüksek lisans, 86'sı da $(\% 17,5)$ lise ve dengi okul mezunu olduklarını belirtmişlerdir.

Tablo I'de yer aldığı gibi iş süreçlerinin yerine getirilmesinde elektronik evrak ve belge sistemleri genel olarak yeterli görülmektedir. Yeterli görülme oranı yöneticiler için $\% 67,7$ 'de kalırken diğer gruplarda $\% 75^{\prime}$ in üzerine çıkmaktadır. Sonuçlar yöneticiler için sınırlı düzeyde sıkıntıların olduğunu göstermektedir (\%22,2). Kurumda yöneticilerin evrak işleri ile ilgili süreçlerin idaresinden sorumlu olması, dolayısıyla yaşanacak sorunlarla doğrudan idarecilerin muhatap olmasının, bu sonuçların ortaya çıkmasında etkili olduğu düşünülmektedir.

Tablo II. Aranılan Bilgi ve Belgelerin İstenilen Yerde ve Zamanda Erişilmesinde Elektronik Arşiv Sisteminin Yeterliliği

\begin{tabular}{lrrrrrrrr}
\hline & $\mathbf{1}$ & $\mathbf{2}$ & $\mathbf{3}$ & $\mathbf{4}$ & $\mathbf{5}$ & $\overline{\mathbf{X}}$ & $\mathbf{\sigma}$ \\
\hline Yönetici & $\%$ & 3 & 17 & 13 & 58 & 8 & 3,51 & 0,97 \\
\multirow{2}{*}{ Uzman } & 3,0 & 17,2 & 13,1 & 58,6 & 8,1 & & \\
& $\%$ & 8,6 & 12,9 & 13,4 & 57,0 & 8,1 & & \\
İdari personel & & 4 & 16 & 19 & 77 & 19 & 3,67 & 0,96 \\
& $\%$ & 3,0 & 11,9 & 14,1 & 57,0 & 14,1 & & \\
Teknik personel & & 3 & 13 & 9 & 35 & 10 & 3,51 & 1,09 \\
& $\%$ & 4,3 & 18,6 & 12,9 & 50,0 & 14,3 & & \\
\hline Toplam & & 26 & 70 & 66 & 276 & 52 & & \\
& & 5,3 & 14,3 & 13,5 & 56,3 & 10,6 & & \\
\hline
\end{tabular}

1. Bütünüyle olumsuz; 2. Olumsuz; 3. Kararsız; 4. Olumlu; 5. Bütünüyle olumlu

Tablo Il'den de anlaşılacağı gibi aranılan bilgi ve belgelerin istenilen yerde ve zamanda erişilmesinde elektronik arşiv sisteminin genel olarak yeterliliği konusunda anket katılımcıları \% 65'in üzerinde olumlu görüş bildirmişlerdir. Kararsızlarla birlikte teknik personel \%35,7 çeşitli düzeylerde sıkıntılardan söz ederken bu oran idari personelde \%29'a düşmektedir. Sistemin kullanımı konusunda idari personelin daha deneyimli olmasının bu sonuçların ortaya çıkmasında etkili olabileceği öngörülmektedir. 
Tablo III. e-İçişleri e-Posta Sisteminin Kurum İçi Bilgi Alışverişi ve İletişimde Yeterliliği

\begin{tabular}{|c|c|c|c|c|c|c|c|c|}
\hline & & 1 & 2 & 3 & 4 & 5 & $\bar{x}$ & $\sigma$ \\
\hline \multirow[t]{2}{*}{ Yönetici } & & 0 & 17 & 23 & 51 & 8 & 3,50 & 0,87 \\
\hline & $\%$ & 0 & 17,2 & 23,2 & 51,5 & 8,1 & & \\
\hline \multirow[t]{2}{*}{ Uzman } & & 15 & 24 & 26 & 96 & 25 & 3,49 & 1,12 \\
\hline & $\%$ & 8,1 & 12,9 & 14,0 & 51,6 & 13,4 & & \\
\hline \multirow[t]{2}{*}{ İdari personel } & & 5 & 18 & 26 & 62 & 24 & 3,60 & 1,04 \\
\hline & $\%$ & 3,7 & 13,3 & 19,3 & 45,9 & 17,8 & & \\
\hline \multirow[t]{2}{*}{ Teknik personel } & & 4 & 13 & 8 & 35 & 10 & 3,48 & 1,12 \\
\hline & $\%$ & 5,7 & 18,6 & 11,4 & 50,0 & 14,3 & & \\
\hline \multirow[t]{2}{*}{ Toplam } & & 24 & 72 & 83 & 244 & 67 & & \\
\hline & $\%$ & 4,9 & 14,7 & 16,9 & 49,8 & 13,7 & & \\
\hline
\end{tabular}

1. Bütünüyle olumsuz; 2. Olumsuz; 3. Kararsız; 4. Olumlu; 5. Bütünüyle olumlu

Tablo III'te yer aldığı gibi e-içişleri e-posta sisteminin kurum içi bilgi alışverişi ve iletişimde yeterliliği konusunda yöneticilerin \%40,4'ü kararsız ya da olumsuz görüş bildirirken bu oran diğer gruplarda \%35'in üzerindedir. Grupların verdikleri yanıtların birbirlerine yakın olduğu tabloda, koşulların yeterli bulunma oranının tüm gruplarda \%60'ın üzerinde oluşu da dikkat çekmektedir. Yine de tüm gruplarda \%35'in üzerinde görülen kararsız ve olumsuz tablonun nedenlerinin araştırılması önemli görülmektedir.

Tablo IV. e-içişleri e-Posta Sisteminin Kurum Dışı Bilgi Alışverişi ve İletişimde Yeterliliği

\begin{tabular}{lrrrrrrrr}
\hline & $\mathbf{1}$ & $\mathbf{2}$ & $\mathbf{3}$ & $\mathbf{4}$ & $\mathbf{5}$ & $\overline{\boldsymbol{x}}$ & $\boldsymbol{\sigma}$ \\
\hline Yönetici & & 3 & 33 & 29 & 30 & 4 & 2,98 & 0,96 \\
\multirow{3}{*}{ Uzman } & $\%$ & 3,0 & 33,3 & 29,3 & 30,3 & 4,0 & & \\
& & 15 & 43 & 34 & 78 & 16 & 3,19 & 1,13 \\
İdari personel & $\%$ & 8,1 & 23,1 & 18,3 & 41,9 & 8,6 & & \\
\multirow{2}{*}{ Teknik personel } & $\%$ & 8,1 & 20,0 & 17,0 & 43,0 & 11,9 & & \\
& & 4 & 14 & 12 & 32 & 8 & 3,37 & 1,10 \\
\hline Toplam & $\%$ & 5,7 & 20,0 & 17,1 & 45,7 & 11,4 & & \\
& & 33 & 117 & 98 & 198 & 44 & & \\
& & 6,7 & 23,9 & 20,0 & 40,4 & 9,0 & & \\
\hline
\end{tabular}

1. Bütünüyle olumsuz; 2. Olumsuz; 3. Kararsız; 4. Olumlu; 5. Bütünüyle olumlu 
İlgili diğer tablolardan farklı olarak Tablo IV'te e-içişleri e-posta sisteminin kurum dışı bilgi alışverişi ve iletişimde yeterliliği konusunda yöneticilerin yalnızca \%34,3'ü olumlu görüş bildirmiştir. Khi kare değeri yöneticiler ile diğer gruplar arasında anlamlı bir farklılık olduğunu doğrulamaktadır (P:0,047<0,05). Bu durum özellikle yöneticilerin diğer kurumlarla iletişimde diğer gruplara göre daha fazla sıkıntı yaşadığını göstermektedir. Yöneticiler için aritmetik ortalama değeri de ortalama değer olan 3.00'ün altında kalmaktadır. Diğer gruplar için de olumlu görüş yüzdesi \%58'in üzerine çıkamamaktadır.

Tablo V. Kurum Dışı İş Süreçlerinin Yerine Getirilmesinde Elektronik Bilgi ve Belge Sisteminin Yeterliliği

\begin{tabular}{lrrrrrrrr}
\hline & $\mathbf{1}$ & $\mathbf{2}$ & $\mathbf{3}$ & $\mathbf{4}$ & $\mathbf{5}$ & $\overline{\boldsymbol{X}}$ & $\boldsymbol{\sigma}$ \\
\hline Yönetici & $\%$ & 4 & 34 & 29 & 27 & 5 & 2,94 & 0,99 \\
\multirow{3}{*}{ Uzman } & 4,0 & 34,3 & 29,3 & 27,3 & 5,1 & & \\
& $\%$ & 7,0 & 19,9 & 24,2 & 43,5 & 5,4 & & \\
İdari personel & & 7 & 19 & 37 & 60 & 12 & 3,37 & 1,00 \\
& $\%$ & 5,2 & 14,1 & 27,4 & 44,4 & 8,9 & & \\
Teknik personel & & 4 & 19 & 20 & 22 & 5 & 3.07 & 1,05 \\
& $\%$ & 5,7 & 27,1 & 28,6 & 31,4 & 7,1 & & \\
\hline Toplam & & 28 & 109 & 131 & 190 & 32 & & \\
& & 5,7 & 22,2 & 26,7 & 38,8 & 6,5 & & \\
\hline
\end{tabular}

1. Bütünüyle olumsuz; 2. Olumsuz; 3. Kararsız; 4. Olumlu; 5. Bütünüyle olumlu

Tablo IV'te olduğu gibi Tablo V'te de kurum dışı iş süreçlerinin yerine getirilmesinde elektronik bilgi ve belge sisteminin yeterliliği konusunda yöneticilerin yalnızca \%32,4'ü olumlu görüş bildirmişlerdir. Teknik personelin kararsızlarla birlikte olumsuz görüş bildirme oranı \%61,4'dür. Gruplar içerisinde olumlu görüş bildirenlerin oranı sadece idari personelde \%50'yi geçmektedir. Khi kare değerleri gruplar arasında anlamlı bir farklılık olduğunu göstermektedir (P: 0,036 < 0,05). Uzman ve idari personelin daha olumlu yaklaşımlarına karşın yönetici ve teknik personelin konuya ilişkin olumsuz görüşleri, uygulayıcılar ile denetleyicileri ve yöneticilerin konuya yaklaşımlarının farklılığı ile açıklanabilir. 
Tablo VI. e-İçişlerinin Kullanımı ve Geliştirilen Yeni Modüller Konusunda Hizmet İçi Eğitiminin Yeterliliği

\begin{tabular}{|c|c|c|c|c|c|c|c|c|}
\hline & & 1 & 2 & 3 & 4 & 5 & $\bar{x}$ & $\sigma$ \\
\hline \multirow[t]{2}{*}{ Yönetici } & & 19 & 28 & 12 & 35 & 5 & 2,78 & 1,25 \\
\hline & $\%$ & 19,2 & 28,3 & 12,1 & 35,4 & 5,1 & & \\
\hline \multirow[t]{2}{*}{ Uzman } & & 24 & 57 & 33 & 59 & 13 & 2,89 & 1,19 \\
\hline & $\%$ & 12,9 & 30,6 & 17,7 & 31,7 & 7,0 & & \\
\hline \multirow[t]{2}{*}{ İdari personel } & & 25 & 37 & 17 & 49 & 7 & 2,82 & 1,25 \\
\hline & $\%$ & 18,5 & 27,4 & 12,6 & 36,3 & 5,2 & & \\
\hline \multirow[t]{2}{*}{ Teknik personel } & & 11 & 24 & 12 & 18 & 5 & 2,74 & 1,21 \\
\hline & $\%$ & 15,7 & 34,3 & 17,1 & 25,7 & 7,1 & & \\
\hline \multirow[t]{2}{*}{ Toplam } & & 79 & 146 & 74 & 161 & 30 & & \\
\hline & $\%$ & 16,1 & 29,8 & 15,1 & 32,9 & 6,1 & & \\
\hline
\end{tabular}

1. Bütünüyle olumsuz; 2. Olumsuz; 3. Kararsız; 4. Olumlu; 5. Bütünüyle olumlu

Grupların tamamının aritmetik ortalama değeri ortanca değer olan 3'ün altındadır. Gruplar için gerek aritmetik ortalama gerekse yüzdelik oranlar açısından en düşük değerler Tablo VI'da çıkmıştır. En olumsuz sonuçlar teknik personele aittir $(\bar{x}: 2,74)$. Hizmet içi eğitimin yeterliliği konusunda yöneticilerin $\% 47,5^{\prime}$ i olumsuz görüş bildirirken, bu diğer gruplar da \%40'ın üzerinde gerçekleşmiştir. Olumlu görüş bildirenlerin oranı tüm gruplar için \%50'nin altında kalmaktadır. Bu sonuçlar kurumda e-içişleri sistemine dönük hizmet içi eğitim beklentilerini ne denli yoğun olduğunu göstermesi bakımından önemlidir.

Tablo VII. e-içişlerinde Yaşanan Sorunlara Dönük Teknik Desteğin Yeterliliği

\begin{tabular}{|c|c|c|c|c|c|c|c|c|}
\hline & & 1 & 2 & 3 & 4 & 5 & $\bar{x}$ & $\boldsymbol{\sigma}$ \\
\hline \multirow[t]{2}{*}{ Yönetici } & & 11 & 27 & 22 & 35 & 4 & 2,93 & 1,11 \\
\hline & $\%$ & 11,1 & 27,3 & 22,2 & 35,4 & 4,0 & & \\
\hline \multirow[t]{2}{*}{ Uzman } & & 20 & 54 & 35 & 59 & 18 & 3,00 & 1,19 \\
\hline & $\%$ & 10,8 & 29,0 & 18,8 & 31,7 & 9,7 & & \\
\hline \multirow[t]{2}{*}{ İdari personel } & & 14 & 32 & 23 & 51 & 15 & 3,15 & 1,20 \\
\hline & $\%$ & 10,4 & 23,7 & 17,0 & 37,8 & 11,1 & & \\
\hline \multirow[t]{2}{*}{ Teknik personel } & & 5 & 13 & 13 & 32 & 7 & 3,32 & 1,11 \\
\hline & $\%$ & 7,1 & 18,6 & 18,6 & 45,7 & 10,0 & & \\
\hline \multirow[t]{2}{*}{ Toplam } & & 50 & 126 & 93 & 177 & 44 & & \\
\hline & $\%$ & 10,2 & 25,7 & 19,0 & 36,1 & 9,0 & & \\
\hline
\end{tabular}

1. Bütünüyle olumsuz; 2. Olumsuz; 3. Kararsız; 4. Olumlu; 5. Bütünüyle olumlu 
Tablo VII'de e-içişlerinde yaşanan sorunlara dönük teknik desteğin yeterliliği konusunda teknik personel dışında diğer gruplarda olumlu görüş bildirme oranı \%50'nin altında kalmaktadır. Aritmetik ortalama değerleri çerçevesinde en sıkıntılı grup yöneticilerdir $(\bar{x}: 2,93)$. Uzmanların \%39,8'i, idari personelin \%34,1'i 1. ve 2. seçenekleri işaretleyerek teknik destek konusunda sorun yaşadıklarını dile getirmişlerdir. Bu oran teknik personelde $\% 25,7^{\prime}$ de kalmaktadır.

Tablo VIII. e-İçişlerinde Yer Alan Bilgi ve Belge Kaynaklarının Uzun Süre Korunmasına Dönük Koşulların Yeterliliği

\begin{tabular}{|c|c|c|c|c|c|c|c|c|}
\hline & & 1 & 2 & 3 & 4 & 5 & $\overline{\boldsymbol{x}}$ & $\sigma$ \\
\hline \multirow[t]{2}{*}{ Yönetici } & & 1 & 10 & 35 & 41 & 12 & 3,53 & 0,87 \\
\hline & $\%$ & 1,0 & 10,1 & 35,4 & 41,4 & 12,1 & & \\
\hline \multirow[t]{2}{*}{ Uzman } & & 11 & 12 & 54 & 89 & 20 & 3,51 & 0,98 \\
\hline & $\%$ & 5,9 & 6,5 & 29,0 & 47,8 & 10,8 & & \\
\hline \multirow[t]{2}{*}{ İdari personel } & & 3 & 11 & 25 & 77 & 19 & 3,72 & 0,88 \\
\hline & $\%$ & 2,2 & 8,1 & 18,5 & 57,0 & 14,1 & & \\
\hline \multirow[t]{2}{*}{ Teknik personel } & & 4 & 6 & 17 & 33 & 10 & 3,55 & 1.03 \\
\hline & $\%$ & 5,7 & 8,6 & 24,3 & 47,1 & 14,3 & & \\
\hline \multirow[t]{2}{*}{ Toplam } & & 19 & 39 & 131 & 240 & 61 & & \\
\hline & $\%$ & 3,9 & 8,0 & 26,6 & 49,0 & 12,5 & & \\
\hline
\end{tabular}

1. Bütünüyle olumsuz; 2. Olumsuz; 3. Kararsız; 4. Olumlu; 5. Bütünüyle olumlu

Tablo VIII'de genel olarak e-içişlerinde yer alan bilgi ve belge kaynaklarının uzun süre korunmasına dönük koşulların olumlu görülme oranı tüm gruplar için \%50'nin üzerindedir. Gruplar içerisinde kararsızlarla birlikte en olumsuz görüşü yöneticiler belirtmişlerdir $(\% 46,5)$. Bu oran idari personelde \%28,8'e düşmektedir. Aritmetik ortalama oranı en düşük grup uzmanlardır $(\bar{x}: 3,51)$.

Tablo IX. Web Sitesinin İçeriği Basit ve Anlaşılırdır

\begin{tabular}{lrrrrrrrr}
\hline & $\mathbf{1}$ & $\mathbf{2}$ & $\mathbf{3}$ & $\mathbf{4}$ & $\mathbf{5}$ & $\overline{\boldsymbol{x}}$ & $\boldsymbol{\sigma}$ \\
\hline Yönetici & & 3 & 10 & 33 & 43 & 10 & 3,47 & 0,92 \\
\multirow{3}{*}{ Uzman } & $\%$ & 3,0 & 10,1 & 33,3 & 43,4 & 10,1 & & \\
\multirow{3}{*}{ Idari personel } & $\%$ & 3,2 & 9,1 & 24,6 & 40,1 & 23,0 & & \\
& & 6 & 17 & 46 & 75 & 43 & 3,70 & 1,02 \\
Teknik personel & $\%$ & 2,2 & 6,7 & 27,4 & 40,7 & 23,0 & & \\
& & 3 & 1 & 15 & 26 & 25 & 3,98 & 1,01 \\
\hline Toplam & $\%$ & 4,3 & 1,4 & 21,4 & 37,1 & 35,7 & & \\
& & 15 & 37 & 131 & 199 & 109 & & \\
& & 3,1 & 7,5 & 26,7 & 40,5 & 22,2 & & \\
\hline
\end{tabular}

1. Bütünüyle olumsuz; 2. Olumsuz; 3. Kararsız; 4. Olumlu; 5. Bütünüyle olumlu 
Tablo IX'da da görüldüğü gibi web sitesi içeriğinin basit ve anlaşılır oluşu konusunda en olumlu düşünen grup teknik personel $(\bar{x}: 3,98)$, en olumsuz düşünen grup ise yöneticilerdir $(\bar{x}: 3,47)$. Khi kare değerlerine göre de iki grubun yanıtları arasında anlamlı bir farklılık vardır. Yöneticilerin \%46,3'ü kararsız ya da olumsuz görüş bildirmişlerdir (P: $0,047<0,05)$. Tabloda yer aldığı gibi teknik personel sorumlu olduğu web sayfasının içeriğini diğer gruplara göre çok daha olumlu görmektedir. Yine diğer değişkenlerle karşılaştırıldığında web içeriği ile ilgili ciddi bir sıkıntının yaşanmadığı anlaşılmaktadır.

Tablo X. Sistem Güvenliği Yeterince Sağlanmaktadır

\begin{tabular}{|c|c|c|c|c|c|c|c|c|}
\hline & & 1 & 2 & 3 & 4 & 5 & $\bar{x}$ & $\sigma$ \\
\hline \multirow[t]{2}{*}{ Yönetici } & & 2 & 10 & 35 & 34 & 18 & 3,56 & 0,97 \\
\hline & $\%$ & 2,0 & 10,1 & 35,4 & 34,3 & 18,2 & & \\
\hline \multirow[t]{2}{*}{ Uzman } & & 9 & 9 & 51 & 73 & 45 & 3,72 & 1,03 \\
\hline & $\%$ & 4,8 & 4,8 & 27,3 & 39,0 & 24,1 & & \\
\hline \multirow[t]{2}{*}{ İdari personel } & & 7 & 9 & 42 & 42 & 35 & 3,65 & 0,99 \\
\hline & $\%$ & 5,2 & 6,7 & 31,1 & 31,1 & 25,9 & & \\
\hline \multirow[t]{2}{*}{ Teknik personel } & & 3 & 3 & 18 & 34 & 12 & 3,70 & 1,05 \\
\hline & $\%$ & 4,3 & 4,3 & 25,7 & 48,6 & 17,1 & & \\
\hline \multirow[t]{2}{*}{ Toplam } & & 21 & 31 & 146 & 183 & 110 & & \\
\hline & $\%$ & 4,3 & 6,3 & 29,7 & 37,3 & 22,4 & & \\
\hline
\end{tabular}

1. Bütünüyle olumsuz; 2. Olumsuz; 3. Kararsız; 4. Olumlu; 5. Bütünüyle olumlu

İçişleri Bakanlığı içerisinde kullanılan elektronik sistemlerin güvenliği konusunda genelde olumlu bir tablo söz konusudur (Tablo X). Tüm gruplarda ortalama \%10 civarında olumsuz görüş vardır. Kullanılan elektronik sistemleri güvenli bulanların oranı teknik personelde $\% 65,8$, uzmanlarda $\% 63,1$ iken, idari personelde $\% 57$, yöneticilerde \%52,5'dir. Bu tabloda yüzdelik değerlerin tabloyu yorumlamada daha anlamlı olduğu düşünüldüğünden aritmetik ortamalar göz önüne alınmamıştır. Nitekim olumlu görüş bildirenlerin yüzdeleri diğer tablolara göre daha fazladır.

Elektronik içeriğe erişimle ilgili en sıkıntılı grup idari personeldir $(\bar{x}: 3,12)$. İdari personelin yaklaşık \%55'i, koşulları kararsız ya da olumsuz görmektedir. Tüm gruplarda koşulları olumsuz görenlerin oranı \%20 ve üzerindedir. Grupların aritmetik ortalama değerlerinin 3,12 ile 3,40 arasına sıkıştığı dolayısıyla ihtiyatlı bir iyimserliğin söz konusu olduğu söylenebilir (Tablo XI). 
Tablo Xı. Elektronik İçeriğe Hızlı ve Etkin Erişim Sağlanabilmektedir

\begin{tabular}{lrrrrrrrr}
\hline & $\mathbf{1}$ & $\mathbf{2}$ & $\mathbf{3}$ & $\mathbf{4}$ & $\mathbf{5}$ & $\overline{\boldsymbol{x}}$ & $\boldsymbol{\sigma}$ \\
\hline Yönetici & & 3 & 17 & 31 & 34 & 14 & 3,39 & 1,03 \\
& $\%$ & 3,0 & 17,2 & 31,3 & 34,3 & 14,1 & & \\
Uzman & $\%$ & 8,6 & 13,4 & 24,1 & 37,4 & 16,6 & & \\
& & 16 & 25 & 45 & 70 & 31 & 3,40 & 1,17 \\
İdari personel & $\%$ & 12,6 & 18,5 & 27,4 & 26,7 & 14,8 & & \\
& & 5 & 9 & 25 & 21 & 10 & 3,31 & 1,10 \\
Teknik personel & $\%$ & 7,1 & 12,9 & 35,7 & 30,0 & 14,3 & & \\
& & 41 & 76 & 138 & 161 & 75 & & \\
\hline Toplam & & 8,3 & 15,5 & 28,1 & 32,8 & 15,3 & & \\
\hline
\end{tabular}

1. Bütünüyle olumsuz; 2. Olumsuz; 3. Kararsız; 4. Olumlu; 5. Bütünüyle olumlu

Tablo XII' ye göre e-içişleri üzerinde resmi işlerin e-imza sertifikası ile yürütülmesi ile ilgili olarak koşulları en olumlu gören grup uzmanlardır $(\bar{x}: 3,60)$. Yöneticilerin \%50'den fazlası e-imza sertifikası ile resmi işlerin yürütülmesi ile ilgili koşulları olumsuz görmekte ya da durumla ilgili kararsız kalmaktadır. İdari personelin \%25'inden fazlası ise koşulları olumsuz görmektedir.

Tablo XII. Sistem Üzerinde Kurumsal Resmi İşlemler (e-İmza Sertifikası İle Sorunsuz Gerçekleşebilmektedir)

\begin{tabular}{lrrrrrrrr}
\hline & $\mathbf{1}$ & $\mathbf{2}$ & $\mathbf{3}$ & $\mathbf{4}$ & $\mathbf{5}$ & $\overline{\boldsymbol{x}}$ & $\boldsymbol{\sigma}$ \\
\hline Yönetici & & 7 & 19 & 21 & 37 & 15 & 3,34 & 1,16 \\
& $\%$ & 7,1 & 19,2 & 21,2 & 37,4 & 15,2 & & \\
Uzman & $\%$ & 6,4 & 9,6 & 23,0 & 38,5 & 22,5 & & \\
& & 12 & 18 & 43 & 72 & 42 & 3,60 & 1,13 \\
İdari personel & & 12 & 23 & 33 & 34 & 33 & 3,39 & 1,27 \\
& & & & & \\
Teknik personel & & 2 & 10 & 24 & 19 & 15 & 3,50 & 1,07 \\
& & 2,9 & 14,3 & 34,3 & 27,1 & 21,4 & & \\
\hline Toplam & & 33 & 70 & 121 & 162 & 105 & & \\
& & 6,7 & 14,3 & 24,6 & 33,0 & 21,4 & & \\
\hline
\end{tabular}

1. Bütünüyle olumsuz; 2. Olumsuz; 3. Kararsız; 4. Olumlu; 5. Bütünüyle olumlu 
Tablo XIII. Sistem Üzerindeki Bilgi ve Belgelerin Güvenilirliği ve Yasal Geçerliliği Sağlanmaktadır

\begin{tabular}{|c|c|c|c|c|c|c|c|c|}
\hline & & 1 & 2 & 3 & 4 & 5 & $\bar{x}$ & $\sigma$ \\
\hline \multirow[t]{2}{*}{ Yönetici } & & & 9 & 31 & 42 & 17 & 3,67 & 0,87 \\
\hline & $\%$ & 0 & 9,1 & 31,3 & 42,4 & 17,2 & & \\
\hline \multirow[t]{2}{*}{ Uzman } & & 4 & 15 & 37 & 78 & 52 & 3,85 & 0,99 \\
\hline & $\%$ & 2,2 & 8,1 & 19,9 & 41,9 & 28,0 & & \\
\hline \multirow[t]{2}{*}{ İdari personel } & & 3 & 6 & 31 & 57 & 38 & 3,89 & 0,94 \\
\hline & $\%$ & 2,2 & 4,4 & 23,0 & 42,2 & 28,1 & & \\
\hline \multirow[t]{2}{*}{ Teknik personel } & & 1 & 0 & 23 & 32 & 14 & 3,82 & 0,80 \\
\hline & $\%$ & 1,4 & 0 & 32,9 & 45,7 & 20,0 & & \\
\hline \multirow[t]{2}{*}{ Toplam } & & 8 & 30 & 122 & 209 & 121 & & \\
\hline & $\%$ & 1,6 & 6,1 & 24,9 & 42,7 & 24,7 & & \\
\hline
\end{tabular}

1. Bütünüyle olumsuz; 2. Olumsuz; 3. Kararsız; 4. Olumlu; 5. Bütünüyle olumlu

Tablo XIII'teki bulgulara göre e-içişleri üzerinde belgelerin güvenilirliği ve geçerliliği konusunda, diğer konularla karşılaştırıldığında daha olumlu bir tablo ortaya çıkmaktadır. Genel olarak grupların \%60'ından fazlası koşulları olumlu değerlendirmektedir. Bu oran idari personelde \%70'in üzerine çıkmaktadır. Yönetici ve teknik personel gruplarında kararsızların oranı \%30'un üzerindedir.

Tablo XIV. Sistem İçerisinde Birbiriyle İlişkili Bilgi ve Belgelerin Bütünlüğü ve Kapsamı Korunmaktadır

\begin{tabular}{lrrrrrrrr}
\hline & $\mathbf{1}$ & $\mathbf{2}$ & $\mathbf{3}$ & $\mathbf{4}$ & $\mathbf{5}$ & $\overline{\boldsymbol{x}}$ & $\boldsymbol{\sigma}$ \\
\hline Yönetici & & 0 & 13 & 31 & 40 & 15 & 3,57 & 0,90 \\
\multirow{2}{*}{ Uzman } & $\%$ & 0,0 & 13,1 & 31,3 & 40,4 & 15,2 & & \\
& $\%$ & 2,2 & 3,8 & 26,9 & 45,7 & 21,5 & & \\
İdari personel & $\%$ & 5 & 7 & 30 & 60 & 33 & 3,80 & 0,99 \\
& & 3,7 & 5,2 & 22,2 & 44,4 & 24,4 & & \\
Teknik personel & & 2 & 4 & 23 & 29 & 12 & 3,64 & 0,93 \\
& $\%$ & 2,9 & 5,7 & 32,9 & 41,4 & 17,1 & & \\
\hline Toplam & & 11 & 31 & 134 & 214 & 100 & & \\
& & 2,2 & 6,3 & 27,3 & 43,7 & 20,4 & & \\
\hline
\end{tabular}

1. Bütünüyle olumsuz; 2. Olumsuz; 3. Kararsız; 4. Olumlu; 5. Bütünüyle olumlu 
Sistem içerisinde birbiriyle ilişkili bilgi ve belgelerin bütünlüğü ve kapsamının korunması ile ilgili Tablo XIV'te yine olumlu bir durum söz konusudur. Olumsuz görenlerin oranı tüm gruplarda \%15'in altında, genel toplamda ise \%10'un altında kalmaktadır. Yönetici ve teknik personel gruplarında kararsızların oranı \%30'un üzerindedir. Sonuçlar anket katılımcılarının belgelerin bütünlüğü ve kamasına ilişkin önemli bir sorun yasmadığını göstermektedir.

Tablo XV. Sistemin Farklı Unsurlarına Personelin Erişim ve Kullanım Yetkilendirilmeleri Sorunsuzdur

\begin{tabular}{lrrrrrrrr}
\hline & $\mathbf{1}$ & $\mathbf{2}$ & $\mathbf{3}$ & $\mathbf{4}$ & $\mathbf{5}$ & $\overline{\boldsymbol{x}}$ & $\mathbf{\sigma}$ \\
\hline Yönetici & & 1 & 21 & 29 & 36 & 12 & 3,37 & 0,98 \\
& $\%$ & 1,0 & 21,2 & 29,3 & 36,4 & 12,1 & & \\
Uzman & & 7 & 20 & 53 & 74 & 32 & 3,55 & 1,01 \\
& $\%$ & 3,8 & 10,8 & 28,5 & 39,8 & 17,2 & & \\
İdari personel & & 7 & 11 & 45 & 47 & 25 & 3,53 & 1,04 \\
& $\%$ & 5,2 & 8,1 & 33,3 & 34,8 & 18,5 & & \\
Teknik personel & & 2 & 11 & 18 & 25 & 14 & 3,54 & 1,07 \\
& $\%$ & 2,9 & 15,7 & 25,7 & 35,7 & 20,0 & & \\
\hline Toplam & & 17 & 63 & 145 & 182 & 83 & & \\
& & 3,5 & 12,9 & 29,6 & 37,1 & 16,9 & & \\
\hline
\end{tabular}

1. Bütünüyle olumsuz; 2. Olumsuz; 3. Kararsız; 4. Olumlu; 5. Bütünüyle olumlu

Sistemin farklı unsurlarına personelin erişim ve kullanım yetkilendirilmeleri ile ilgili yönetici ve teknik personel \%20'den fazlası çeşitli düzeylerde sorun yaşamaktadırlar. Kararsızlarla birlikte sorun yaşayanların oranı tüm gruplarda \%40'ın üzerine çıkmaktadır. Uzmanların \%56'sı ise koşulları olumlu olarak değerlendirmektedir.

Tablo XVI. Sistem Güncellemeleri Yeterli Sıklıkta Yapılmaktadır

\begin{tabular}{lrrrrrrrr}
\hline & & $\mathbf{1}$ & $\mathbf{2}$ & $\mathbf{3}$ & $\mathbf{4}$ & $\mathbf{5}$ & $\overline{\boldsymbol{x}}$ & $\boldsymbol{\sigma}$ \\
\hline Yönetici & & 0 & 9 & 34 & 37 & 19 & 3,66 & 0,89 \\
& $\%$ &, 0 & 9,1 & 34,3 & 37,4 & 19,2 & & \\
Uzman & & 7 & 10 & 48 & 77 & 44 & 3,75 & 1,00 \\
& $\%$ & 3,8 & 5,4 & 25,8 & 41,4 & 23,7 & & \\
İdari personel & & 5 & 12 & 27 & 59 & 32 & 3,74 & 1,03 \\
& $\%$ & 3,7 & 8,9 & 20,0 & 43,7 & 23,7 & & \\
Teknik personel & & 1 & 7 & 22 & 25 & 15 & 3,65 & 0,98 \\
& $\%$ & 1,4 & 10,0 & 31,4 & 35,7 & 21,4 & & \\
\hline Toplam & & 13 & 38 & 131 & 198 & 110 & & \\
& & 2,7 & 7,8 & 26,7 & 40,4 & 22,4 & & \\
\hline
\end{tabular}

1. Bütünüyle olumsuz; 2. Olumsuz; 3. Kararsız; 4. Olumlu; 5. Bütünüyle olumlu 
Tablo XVI'da yer aldığı gibi sistem güncellemeleri konusunda genel olarak olumlu bir tablo söz konusudur. Genel yüzdelerde koşulları olumlu görenlerin oranı \%60'ın üzerinde iken olumsuz görenlerin oranı \%10,5'te kalmaktadır. Yine \%26,7'nin karasız görüş bildirdikleri görülmektedir. Genel olarak değerlendirildiğinde grupların oranları birbirlerine yakın yüzdelerde çıkmıştır. Sistemin güncelleştirilmesi konusunda ciddi bir sıkıntılını yaşanmadığı söylenebilir.

Tablo XVII. Sistem Üzerinde Verilere Tekrar Erişimi Sorunsuzdur

\begin{tabular}{|c|c|c|c|c|c|c|c|c|}
\hline & & 1 & 2 & 3 & 4 & 5 & $\bar{x}$ & $\sigma$ \\
\hline \multirow[t]{2}{*}{ Yönetici } & & 1 & 12 & 30 & 35 & 21 & 3,63 & 0,98 \\
\hline & $\%$ & 1,0 & 12,1 & 30,3 & 35,4 & 21,2 & & \\
\hline \multirow[t]{2}{*}{ Uzman } & & 6 & 14 & 54 & 71 & 41 & 3,68 & 1,00 \\
\hline & $\%$ & 3,2 & 7,5 & 29,0 & 38,2 & 22,0 & & \\
\hline \multirow[t]{2}{*}{ İdari personel } & & 3 & 10 & 37 & 52 & 33 & 3,75 & 0,98 \\
\hline & $\%$ & 2,2 & 7,4 & 27,4 & 38,5 & 24,4 & & \\
\hline \multirow[t]{2}{*}{ Teknik personel } & & 1 & 4 & 23 & 30 & 12 & 3,68 & 0,88 \\
\hline & $\%$ & 1,4 & 5,7 & 32,9 & 42,9 & 17,1 & & \\
\hline \multirow[t]{2}{*}{ Toplam } & & 11 & 40 & 144 & 188 & 107 & & \\
\hline & $\%$ & 2,2 & 8,2 & 29,4 & 38,4 & 21,8 & & \\
\hline
\end{tabular}

1. Bütünüyle olumsuz; 2. Olumsuz; 3. Kararsız; 4. Olumlu; 5. Bütünüyle olumlu

Sistem üzerindeki verilere tekrar erişim ile ilgili değerlendirilmelerde grupların \%60'tan çoğu koşulları olumlu değerlendirirken olumsuz görenlerin oranı \%10,4'tür. Öte yandan grupların \%30 civarında koşullar konusunda kararsız kaldıkları görülürken, bu oran teknik personelde \%32,9'a çıkmaktadır. Grupların yanıtlarının birbirine yakın olduğu genel olarak ihtiyatlı bir iyimserliğin söz konusu olduğu söylenebilir (Tablo XVII).

Tablo XVIII. İçeriğin Arşivlenmesi ve Uzun Süre Korunması Sorunsuzdur

\begin{tabular}{lrrrrrrrr}
\hline & $\mathbf{1}$ & $\mathbf{2}$ & $\mathbf{3}$ & $\mathbf{4}$ & $\mathbf{5}$ & $\overline{\boldsymbol{x}}$ & $\mathbf{\sigma}$ \\
\hline Yönetici & & 23 & 24 & 28 & 20 & 4 & 2.57 & 1,17 \\
& $\%$ & 23,2 & 24,2 & 28,3 & 20,2 & 4,0 & & \\
Uzman & & 27 & 24 & 53 & 54 & 28 & 3,17 & 1,26 \\
& $\%$ & 14,5 & 12,9 & 28,5 & 29,0 & 15,1 & & \\
İdari personel & & 20 & 29 & 43 & 25 & 18 & 2,94 & 1,24 \\
& $\%$ & 14,8 & 21,5 & 31,9 & 18,5 & 13,3 & & \\
Teknik personel & & 17 & 22 & 15 & 12 & 4 & 2,48 & 1,20 \\
& $\%$ & 24,3 & 31,4 & 21,4 & 17,1 & 5,7 & & \\
\hline Toplam & & 87 & 99 & 139 & 111 & 54 & & \\
& & 17,8 & 20,2 & 28,4 & 22,7 & 11,0 & & \\
\hline
\end{tabular}

1. Bütünüyle olumsuz; 2. Olumsuz; 3. Kararsız; 4. Olumlu; 5. Bütünüyle olumlu 
Tablo XVIII'de yer alan veriler incelendiğinde İçişleri Bakanlığında kullanılan e-bilgi ve belge sistemleri içerisinde en olumsuz tablonun içeriğin arşivlenmesi ve uzun süre korunmasında olduğu görülmektedir. 4. ve 5. şıkları işaretleyerek koşulları olumlu görenlerin oranı genel olarak \%33,7'de kalmaktadır. Koşulları olumlu görenlerin oranı yöneticilerde \%24,2 teknik personelde \%22,8'de kalırken, idari personelde \%31,8 uzmanlarda \%44,5'e çıkmaktadır. Khi kare değerleri de grupların yanıtları arasında anlamlı farklılıklar olduğunu doğrulamaktadır (P: 0,001<0,05). Özellikle teknik personelin elektronik kayıtların yapısını daha yakından tanımasının, uzun süre koruma ile ilgili daha endişeli olmalarında etkili olduğu söylenebilir.

Tablo XIX. Sistemi Öğrenmek ve Sistemdeki Yeniliklere Adapte Olmakta Zorluk Çekilmemektedir

\begin{tabular}{|c|c|c|c|c|c|c|c|c|}
\hline & & 1 & 2 & 3 & 4 & 5 & $\bar{x}$ & $\sigma$ \\
\hline \multirow[t]{2}{*}{ Yönetici } & & 0 & 10 & 27 & 41 & 21 & 3,73 & 0,91 \\
\hline & $\%$ & 0 & 10,1 & 27,3 & 41,4 & 21,2 & & \\
\hline \multirow[t]{2}{*}{ Uzman } & & 5 & 8 & 52 & 80 & 41 & 3,77 & 0,93 \\
\hline & $\%$ & 2,7 & 4,3 & 28,0 & 43,0 & 22,0 & & \\
\hline \multirow[t]{2}{*}{ İdari personel } & & 2 & 7 & 35 & 62 & 29 & 3,80 & 0,88 \\
\hline & $\%$ & 1,5 & 5,2 & 25,9 & 45,9 & 21,5 & & \\
\hline \multirow[t]{2}{*}{ Teknik personel } & & 2 & 6 & 20 & 33 & 9 & 3,58 & 0,92 \\
\hline & $\%$ & 2,9 & 8,6 & 28,6 & 47,1 & 12,9 & & \\
\hline \multirow[t]{2}{*}{ Toplam } & & 9 & 31 & 134 & 216 & 100 & & \\
\hline & $\%$ & 1,8 & 6,3 & 27,3 & 44,1 & 20,4 & & \\
\hline
\end{tabular}

1. Bütünüyle olumsuz; 2. Olumsuz; 3. Kararsız; 4. Olumlu; 5. Bütünüyle olumlu

Tablo XIX'a göre sistemi öğrenmek ve sistemdeki yeniliklere adapte olmakta gruplar genel olarak \%10'un altında zorluk yaşadıklarını dile getirmişlerdir. İdari personelin $\% 67,4$ 'ü ilgili konuda herhangi bir sıkıntı yaşamadığını dile getirirken, bu oran diğer gruplarda da \%60'ın üzerindedir. Bu sonuçlar genel olarak personelin sistemi öğrenme ve yeniliklere adaptasyon konusunda ciddi sıkıntı yalamadıklarını göstermektedir. İlgili konuda idari personelin sistemi sürekli kullanmasının adaptasyon sorununu daha az yaşamasında etkili olduğu düşünülebilir.

Anket katılımcıları sistem üzerinde gerekli tüm iş süreçlerinin tanımlanması ile ilgili koşulları genel olarak olumlu görmekle birlikte $(\% 54,9)$, kararsızların sayısının da azımsanmayacak düzeyde olduğu anlaşılmaktadır $(\% 45,2)$. Bu sonuçların ortaya çıkmasında grupların sistemin yeni hangi unsulara sahip olabileceği konusunda teknik bilgilerinin yetersiz olmasının etkili olduğu düşünülmektedir (Tablo XX). 
Tablo XX. Sistem Üzerinde Gerekli Tüm İ̧̧ Süreçleri Yapılandırılmıştır

\begin{tabular}{|c|c|c|c|c|c|c|c|c|}
\hline & & 1 & 2 & 3 & 4 & 5 & $\overline{\boldsymbol{x}}$ & $\boldsymbol{\sigma}$ \\
\hline \multirow[t]{2}{*}{ Yönetici } & & & 11 & 28 & 33 & 21 & 3,52 & 1,13 \\
\hline & $\%$ & 6,1 & 11,1 & 28,3 & 33,3 & 21,2 & & \\
\hline \multirow[t]{2}{*}{ Uzman } & & 4 & 27 & 46 & 72 & 37 & 3,59 & 1,03 \\
\hline & $\%$ & 2,2 & 14,5 & 24,7 & 38,7 & 19,9 & & \\
\hline \multirow[t]{2}{*}{ İdari personel } & & 5 & 19 & 43 & 45 & 23 & 3,45 & 1,04 \\
\hline & $\%$ & 3,7 & 14,1 & 31,9 & 33,3 & 17,0 & & \\
\hline \multirow[t]{2}{*}{ Teknik personel } & & 6 & 4 & 22 & 27 & 11 & 3,47 & 1,09 \\
\hline & $\%$ & 8,6 & 5,7 & 31,4 & 38,6 & 15,7 & & \\
\hline \multirow[t]{2}{*}{ Toplam } & & 21 & 61 & 139 & 177 & 92 & & \\
\hline & $\%$ & 4,3 & 12,4 & 28,4 & 36,1 & 18,8 & & \\
\hline
\end{tabular}

1. Bütünüyle olumsuz; 2. Olumsuz; 3. Kararsız; 4. Olumlu; 5. Bütünüyle olumlu

Tablo XXI'e göre grupların sistemin hatasız bir şekilde işlediğine dönük olumlu yanıtları \%50'nin altında kalmaktadır. Koşullarla ilgili özellikle kararsızların ağırlıkta olduğu görülmektedir. Koşulları en çok teknik personel olumsuz görmektedir. Sonuçlar tüm gruplar için sistemin çeşitli düzeylerde hatalara sahip olduğunu ortaya koymaktadır. Bu sonuçlar aynı zamanda sistemin iyileştirilmesine dönük beklentilerin ne derece yüksek olduğunu göstermesi bakımından önemlidir.

Tablo XXI. Sistem Hatasız Bir Şekilde İşlemektedir

\begin{tabular}{|c|c|c|c|c|c|c|c|c|}
\hline & & 1 & 2 & 3 & 4 & 5 & $\bar{x}$ & $\sigma$ \\
\hline \multirow[t]{2}{*}{ Yönetici } & & 2 & 16 & 36 & 36 & 9 & 3,34 & 0,93 \\
\hline & $\%$ & 2,0 & 16,2 & 36,4 & 36,4 & 9,1 & & \\
\hline \multirow[t]{2}{*}{ Uzman } & & 8 & 25 & 63 & 63 & 27 & 3,40 & 1,03 \\
\hline & $\%$ & 4,3 & 13,4 & 33,9 & 33,9 & 14,5 & & \\
\hline \multirow[t]{2}{*}{ İdari personel } & & 5 & 17 & 52 & 39 & 22 & 3,41 & 1,02 \\
\hline & $\%$ & 3,7 & 12,6 & 38,5 & 28,9 & 16,3 & & \\
\hline \multirow[t]{2}{*}{ Teknik personel } & & 2 & 15 & 26 & 20 & 7 & 3,21 & 0,99 \\
\hline & $\%$ & 2,9 & 21,4 & 37,1 & 28,6 & 10,0 & & \\
\hline \multirow[t]{2}{*}{ Toplam } & & 17 & 73 & 177 & 158 & 65 & & \\
\hline & $\%$ & 3,5 & 14,9 & 36,1 & 32,2 & 13,3 & & \\
\hline
\end{tabular}

1. Bütünüyle olumsuz; 2. Olumsuz; 3. Kararsız; 4. Olumlu; 5. Bütünüyle olumlu 
Tablo XXII. Sistem Yeni Koşullarına Adapte Olmaktadır

\begin{tabular}{|c|c|c|c|c|c|c|c|c|}
\hline & & 1 & 2 & 3 & 4 & 5 & $\bar{x}$ & $\sigma$ \\
\hline \multirow[t]{2}{*}{ Yönetici } & & 9 & 19 & 34 & 29 & 8 & 3,08 & 1,08 \\
\hline & $\%$ & 9,1 & 19,2 & 34,3 & 29,3 & 8,1 & & \\
\hline \multirow[t]{2}{*}{ Uzman } & & 17 & 35 & 57 & 58 & 19 & 3,14 & 1,12 \\
\hline & $\%$ & 9,1 & 18,8 & 30,6 & 31,2 & 10,2 & & \\
\hline \multirow[t]{2}{*}{ İdari personel } & & 20 & 32 & 36 & 27 & 20 & 2,96 & 1,28 \\
\hline & $\%$ & 14,8 & 23,7 & 26,7 & 20,0 & 14,8 & & \\
\hline \multirow[t]{2}{*}{ Teknik personel } & & 8 & 13 & 27 & 20 & 2 & 2,92 & 1,03 \\
\hline & $\%$ & 11,4 & 18,6 & 38,6 & 28,6 & 2,9 & & \\
\hline \multirow[t]{2}{*}{ Toplam } & & 54 & 99 & 154 & 134 & 49 & & \\
\hline & $\%$ & 11,0 & 20,2 & 31,4 & 27,3 & 10,0 & & \\
\hline
\end{tabular}

1. Bütünüyle olumsuz; 2. Olumsuz; 3. Kararsız; 4. Olumlu; 5. Bütünüyle olumlu

Sistemin yeni koşullara adaptasyonu ile ilgili olan Tablo XXII'de genel olarak olumsuz bir durum söz konusudur. Özellikle teknik personel ve idari personel aritmetik ortalama değerlerinin 3 'ün altında kaldığı görülmektedir. Diğer gruplara göre nispeten olumlu yanıt veren uzmanların da \%58'den fazlası koşulları olumlu görmemektedir. Sonuçlar sistemin yeni koşullara adaptasyonu konusunda iyileştirmelere gereksinim duyduğunu göstermektedir.

Tablo XXIII. Sistem Üzerinde İ̧ Süreçleri Yasal Gereklilikleri Karşılamaktadır

\begin{tabular}{|c|c|c|c|c|c|c|c|c|}
\hline & & 1 & 2 & 3 & 4 & 5 & $\bar{x}$ & $\sigma$ \\
\hline \multirow[t]{2}{*}{ Yönetici } & & 4 & 18 & 36 & 29 & 12 & 3,27 & 1,03 \\
\hline & $\%$ & 4,0 & 18,2 & 36,4 & 29,3 & 12,1 & & \\
\hline \multirow[t]{2}{*}{ Uzman } & & 3 & 21 & 63 & 69 & 30 & 3,54 & 0,95 \\
\hline & $\%$ & 1,6 & 11,3 & 33,9 & 37,1 & 16,1 & & \\
\hline \multirow[t]{2}{*}{ İdari personel } & & 8 & 30 & 37 & 33 & 27 & 3,30 & 1,19 \\
\hline & $\%$ & 5,9 & 22,2 & 27,4 & 24,4 & 20,0 & & \\
\hline \multirow[t]{2}{*}{ Teknik personel } & & 7 & 11 & 22 & 24 & 6 & 3,15 & 1,11 \\
\hline & $\%$ & 10,0 & 15,7 & 31,4 & 34,3 & 8,6 & & \\
\hline \multirow[t]{2}{*}{ Toplam } & & 22 & 80 & 158 & 155 & 75 & & \\
\hline & $\%$ & 4,5 & 16,3 & 32,2 & 31,6 & 15,3 & & \\
\hline
\end{tabular}

1. Bütünüyle olumsuz; 2. Olumsuz; 3. Kararsı; 4. Olumlu; 5. Bütünüyle olumlu 
Yasal gereklilikler çerçevesinde sistem üzerinde iş ve işlemlerin yürütülebilmesi ile ilgili Tablo XXIII'e göre grupların genel olarak \%46,9'u koşulları olumlu görmektedir. Aritmetik ortalama değerleri teknik personelde 3,15'de kalırken bu oran uzmanlarda 3,54'e yükselmektedir. Khi kare değerleri gruplar arasında verilen yanıtlara yönelik farklılık olduğunu doğrulamaktadır (P: 0,013<0,05). Özellikle teknik personelin elektronik sistemlerin yasal koşullarının iyileştirilmesine dönük beklentilerinin karşılanması gerekmektedir.

Tablo XXIV. Sistem Üzerinde Farklı İş Süreçleri Birbiriyle Entegre Edilebilmektedir

\begin{tabular}{lrrrrrrrr}
\hline & $\mathbf{1}$ & $\mathbf{2}$ & $\mathbf{3}$ & $\mathbf{4}$ & $\mathbf{5}$ & $\overline{\boldsymbol{x}}$ & $\boldsymbol{\sigma}$ \\
\hline Yönetici & & 0 & 12 & 30 & 43 & 14 & 3,59 & 0,88 \\
\multirow{2}{*}{ Uzman } & $\%$ &, 0 & 12,1 & 30,3 & 43,4 & 14,1 & & \\
& $\%$ & 1,6 & 9,1 & 26,3 & 45,2 & 17,7 & & \\
İari personel & & 4 & 6 & 43 & 52 & 30 & 3,72 & 0,96 \\
& $\%$ & 3,0 & 4,4 & 31,9 & 38,5 & 22,2 & & \\
Teknik personel & & 0 & 5 & 24 & 32 & 9 & 3,64 & 0,80 \\
& $\%$ &, 0 & 7,1 & 34,3 & 45,7 & 12,9 & & \\
\hline Toplam & & 7 & 40 & 146 & 211 & 86 & & \\
& & 1,4 & 8,2 & 29,8 & 43,1 & 17,6 & & \\
\hline
\end{tabular}

1. Bütünüyle olumsuz; 2. Olumsuz; 3. Kararsız; 4. Olumlu; 5. Bütünüyle olumlu

Tablo XXIV'te sistem üzerinde farklı iş süreçlerinin birbiriyle entegre edilebilmesi konusunda genel olarak olumlu bir tablo söz konusudur (Genel toplamda olumlu yanıtların oranı \%60,7). Koşulları olumsuz görenlerin oranı tüm gruplar için \%15'in altındadır. Kararsızların oranı \%30 civarındadır. Sonuçlar sistemin farklı iş süreçlerinin entegrasyonu konusunda genel olarak sorun yaşanmadığını ortaya koymaktadır.

Kurum çalışanlarının sistem üzerinde gerçekleştirilebilecekleri uygulamalara yönelik farkındalıkları konusunda olan Tablo XXV'e göre olumlu yanıtların oranı tüm gruplarda \%50'nin altında kalmaktadır. Bu oran teknik personelde \%34,2'ye düşerken, yöneticilerde \%41,4'dür. Koşulları olumlu görenlerin oranı idari personelde \%48,9'a yükselmektedir. Yönetici ve teknik personel, çalışanların sistem üzerinde yapabilecekleri uygulamaların farkındalıkları konusunda idari personel ve uzmanlara göre daha olumsuz görüş bildirmişlerdir. Bu sonuçlar yetkili ve teknik personelin sistem özellikleri konusunda daha fazla bilgilendirme ihtiyacına sahip olduklarını göstermektedir. 
Tablo XXV. Kurum Çalışanları Sistem Üzerinde Gerçekleştirilebilecek Uygulamaların Farkındadırlar

\begin{tabular}{|c|c|c|c|c|c|c|c|c|}
\hline & & 1 & 2 & 3 & 4 & 5 & $\bar{x}$ & $\boldsymbol{\sigma}$ \\
\hline \multirow[t]{2}{*}{ Yönetici } & & 7 & 19 & 32 & 31 & 10 & 3,18 & 1,08 \\
\hline & $\%$ & 7,1 & 19,2 & 32,3 & 31,3 & 10,1 & & \\
\hline \multirow[t]{2}{*}{ Uzman } & & 5 & 16 & 74 & 62 & 29 & 3,50 & 0,95 \\
\hline & $\%$ & 2,7 & 8,6 & 39,8 & 33,3 & 15,6 & & \\
\hline \multirow[t]{2}{*}{ İdari personel } & & 5 & 19 & 45 & 43 & 23 & 3,44 & 1,04 \\
\hline & $\%$ & 3,7 & 14,1 & 33,3 & 31,9 & 17,0 & & \\
\hline \multirow[t]{2}{*}{ Teknik personel } & & 2 & 13 & 31 & 19 & 5 & 3,17 & 0,92 \\
\hline & $\%$ & 2,9 & 18,6 & 44,3 & 27,1 & 7,1 & & \\
\hline \multirow[t]{2}{*}{ Toplam } & & 19 & 67 & 182 & 155 & 67 & & \\
\hline & $\%$ & 3,9 & 13,7 & 37,1 & 31,6 & 13,7 & & \\
\hline
\end{tabular}

1. Bütünüyle olumsuz; 2. Olumsuz; 3. Kararsız; 4. Olumlu; 5. Bütünüyle olumlu

TabloXXVI'ya göre İçişleri Bakanlığında kullanılan e-bilgi ve belgeyönetimi sistemlerinin genel olarak basılı sistemlere göre maliyet avantajı getirdiği düşünülmektedir. Aritmetik ortalama değerleri çerçevesinde maliyet avantajı konusunda idari personel $(\bar{x}: 3,65)$ ve uzmanlar $(\bar{x}: 3,63)$ daha olumlu düşünürken bu oran teknik personelde 3,14'e kadar düşmektedir. Bu durum idari süreçleri yürüten personelin basılı sistemlere göre çıktı alma, kağıt vb. masrafları düşünerek elektronik sistemleri daha avantajı görmelerine karşın teknik personelin yazılım ve donanım giderlerini öncelikle göz önüne almaları ile açıklanabilir.

Tablo XXVI. Sistem Üzerinde Daha Önce Basılı Ortamda Yürütülen İşler Daha Az Maliyetle Gerçekleşmektedirler

\begin{tabular}{lrrrrrrrr}
\hline & $\mathbf{1}$ & $\mathbf{2}$ & $\mathbf{3}$ & $\mathbf{4}$ & $\mathbf{5}$ & $\overline{\boldsymbol{x}}$ & $\boldsymbol{\sigma}$ \\
\hline Yönetici & & 3 & 14 & 30 & 33 & 19 & 3,51 & 0,10 \\
& $\%$ & 3,0 & 14,1 & 30,3 & 33,3 & 19,2 & & \\
Uzman & $\%$ & 3,2 & 8,6 & 30,6 & 36,0 & 21,5 & & \\
\multirow{2}{*}{ İdari personel } & 6 & 16 & 57 & 67 & 40 & 3,63 & 0,07 \\
& & 7 & 11 & 34 & 52 & 31 & 3,65 & 0,09 \\
Teknik personel & $\%$ & 5,2 & 8,1 & 25,2 & 38,5 & 23,0 & & \\
& & 8 & 12 & 21 & 20 & 9 & 3,14 & 0,14 \\
\hline Toplam & $\%$ & 11,4 & 17,1 & 30,0 & 28,6 & 12,9 & & \\
& & 24 & 53 & 142 & 172 & 99 & & \\
& & 4,9 & 10,8 & 29,0 & 35,1 & 20,2 & & \\
\hline
\end{tabular}

1. Bütünüyle olumsuz; 2. Olumsuz; 3. Kararsız; 4. Olumlu; 5. Bütünüyle olumlu 
Tablo XXVII. Sistemin İşletilmesi ve Kullanıcı Sorunlarının Karşılanması Konusunda Yeterli Personel Vardır

\begin{tabular}{lrrrrrrrr}
\hline & $\mathbf{1}$ & $\mathbf{2}$ & $\mathbf{3}$ & $\mathbf{4}$ & $\mathbf{5}$ & $\overline{\boldsymbol{x}}$ & $\boldsymbol{\sigma}$ \\
\hline Yönetici & $\%$ & 4 & 11 & 12 & 30 & 42 & 3,95 & 1,05 \\
& & 4,0 & 11,1 & 12,1 & 30,3 & 42,4 & & \\
Uzman & $\%$ & 4,8 & 3,2 & 18,3 & 37,1 & 36,6 & & \\
\multirow{3}{*}{ İdari personel } & & 7 & 6 & 20 & 44 & 58 & 4,03 & 1,08 \\
& $\%$ & 5,2 & 4,4 & 14,8 & 32,6 & 43,0 & & \\
Teknik personel & & 5 & 2 & 21 & 22 & 20 & 3,71 & 1,19 \\
& $\%$ & 7,1 & 2,9 & 30,0 & 31,4 & 28,6 & & \\
\hline Toplam & & 25 & 25 & 87 & 165 & 188 & & \\
& & 5,1 & 5,1 & 17,8 & 33,7 & 38,4 & & \\
\hline
\end{tabular}

1. Bütünüyle olumsuz; 2. Olumsuz; 3. Kararsız; 4. Olumlu; 5. Bütünüyle olumlu

Tablo XXVII'ye göre katılımcılar genel olarak e-bilgi ve belge yönetimi sistemlerinin işletilmesi konusunda yeterli personel olduğunu düşünmektedir. Olumsuz düşünenlerin oranı tüm gruplar için \%12'nin altında kalmaktadır. Aritmetik ortalama değerleri incelendiğinde idari personel için 4,03'e çıkarken bu oranın teknik personelde 3,71'de kaldığı görülmektedir. Genel olarak sonuçlar kurumda sistemin işletilmesi konusunda yeterli personelin olduğunu ortaya koymaktadır.

Tablo XXVIII. Sistem e-Devlet Gereksinimlerini Yeterince Karşılamaktadır

\begin{tabular}{|c|c|c|c|c|c|c|c|c|}
\hline & & 1 & 2 & 3 & 4 & 5 & $\bar{x}$ & $\sigma$ \\
\hline \multirow[t]{2}{*}{ Yönetici } & & 10 & 23 & 29 & 27 & 10 & 3,04 & 1,17 \\
\hline & $\%$ & 10,1 & 23,2 & 29,3 & 27,3 & 10,1 & & \\
\hline \multirow[t]{2}{*}{ Uzman } & & 16 & 22 & 65 & 52 & 31 & 3,32 & 1,06 \\
\hline & $\%$ & 8,6 & 11,8 & 34,9 & 28,0 & 16,7 & & \\
\hline \multirow[t]{2}{*}{ İdari personel } & & 14 & 19 & 41 & 32 & 29 & 3,31 & 1,11 \\
\hline & $\%$ & 10,4 & 14,1 & 30,4 & 23,7 & 21,5 & & \\
\hline \multirow[t]{2}{*}{ Teknik personel } & & 9 & 6 & 24 & 20 & 11 & 3,25 & 1,13 \\
\hline & $\%$ & 12,9 & 8,6 & 34,3 & 28,6 & 15,7 & & \\
\hline \multirow[t]{2}{*}{ Toplam } & & 49 & 70 & 159 & 131 & 81 & & \\
\hline & $\%$ & 10,0 & 14,3 & 32,4 & 26,7 & 16,5 & & \\
\hline
\end{tabular}

1. Bütünüyle olumsuz; 2. Olumsuz; 3. Kararsız; 4. Olumlu; 5. Bütünüyle olumlu 
Tablo XXVIII'e göre kullanılan e-bilgi ve belge yönetimi sisteminin e-devlet gereksinimlerini karşılaması konusunda kararsıza yakın bir iyimserlik söz konusudur. 4. ve 5 . seçenekleri işaretleyerek koşulları olumlu görenlerin oranı tüm gruplar için \%50'nin altında kalmaktadır. Aritmetik ortalama değerleri incelendiğinde koşulları en olumsuz gören grup yöneticilerdir ( $\bar{x}: 3,04)$. Sonuçlar e-içişlerinin mevcut yapısı ile e-devlet kapsamındaki gereksinimleri karşılamada tam olarak yeterli olmadığını göstermektedir.

\section{Sonuç ve Öneriler}

Elde edilen sonuçlar çerçevesinde İçişleri Bakanlığında kurum içi iş süreçlerinin yerine getirilmesinde kullanılan elektronik evrak ve belge yönetimi sistemleri genel olarak yeterli görülmektedir. Ancak kararsızlar da katıldığında yöneticilerin \%30'dan fazlasının konuyla ilgili olumlu görüş bildirmemiş olması dikkat çekmektedir. e-İçişleri e-posta sisteminin kurum içi ve kurum dışı bilgi alışverişi ve iletişimde yeterliliği konusunda genel olarak gruplar olumsuza yakın bir durum söz konusudur. e-içiş̧lerinin kişisel arşiv ve diğer kişisel işlemlerde (personel, ajanda, izin işleri vb.) yeterliliği konusunda elde edilen sonuçlar, analiz edilen diğer başlıklara göre daha olumsuzdur. Analizler, kurum dışı iş süreçlerinin yerine getirilmesinde elektronik bilgi ve belge sisteminin yeterliliği konusunda ortaya çıkan tablonun çok da iç açıcı olmadığını göstermektedir. Bu konuda gruplar arasında sadece idari personelde olumlu görüş bildirenlerin oranı \%50'yi geçebilmektedir. e-iç̧işleri sistemi içerisinde yer alan uygulamaların değerlendirilmesine ilişkin en olumsuz yanıtlar e-iç̧işleri kullanımı ve geliştirilen yeni modüller konusunda hizmet içi eğitimin yeterliliğinde ortaya çıkmıştır. Sonuçlara göre e-içişlerinde yaşanan sorunlara ilişkin teknik desteğin yeterliliği konusunda da ciddi sıkıntılar söz konusudur.

Elektronik içeriğe hızlı ve etkin erişimle ilgili koşullar değerlendirildiğinde ise en sıkıntılı grubun idari personel olduğu görülmektedir. e-i̇çişleri kurumsal bilgi sistemini kurumsal iş süreçlerinde en yoğun kullanan grubun idari personel olduğu göz önüne alındığında elektronik içeriğe hızlı ve etkin erişimde sıkıntıların olması önemli bir sonuç olarak karşımıza çıkmaktadır. e-iç̧ş̧leri kurumsal bilgi sistemi üzerinde resmi iş ve işlemlerin e-imza sertifikası ile sorunsuz yürütülmesi ile ilgili analizlerde uzmanların daha olumlu yaklaşımlarına karşın yöneticilerin olumsuz görüşleri ön plana çıkmaktadır. Bu durum yöneticilerin kurumsal elektronik belge yönetimi uygulamaları ve e-imza ile ilgili daha fazla teknik destek ve oryantasyon gereksinimi olduğunu göstermektedir.

Sistem içerisinde birbiriyle ilişkili bilgi ve belgelerin bütünlüğü ve kapsamının korunması ile ilgili koşullar genel olarak olumlu görünmekle birlikte yönetici ve teknik personelin çekinceleri göz önüne alınmak durumundadır. e-iç̧işleri erişim ve kullanım yetkilendirilmeleri ile ilgili analizlerde tüm gruplarda \%40'ın üzerinde çeşitli düzeylerde çekincelerin olması dikkat çekici bir sonuçtur. Bu durum kurumsal hiyerarşi ve görev tanımları çerçevesinde sistem üzerinde iş akışlarının gözden geçirilmesi gerekliliğini ön plana çıkarmaktadır. Sistemin güncellenme sıklığının yeterliliği konusunda teknik personel ve yöneticiler koşulları diğer gruplara göre daha olumsuz görmektedir. 
Katılımcılar e-iç̧işleri içerisinde en olumsuz koşulların içeriğin uzun süre korunması ve arşivlenmesinde olduğunu ifade etmektedirler. Bu durum kullanılan sistemde içeriğin korunması ve e-arşiv konusunda kullanıcıların ciddi endişeleri olduğunu göstermektedir. Sonuçlar, mevcut sistemin işleyiş̧i konusunda ciddi sıkıntılar yaşamayan deneklerin, sistem üzerindeki verilerin uzun süre arşivlenmesi, çeşitli tehlikelere karşı korunması ve gelecekte aynı bütünlük içerisinde elde edilebilmesi konusunda sisteme yeterince güvenmediklerini göstermektedir. Kurumsal bilgi sistemlerinin en önemli bileşenlerinden olan e-arşivlerin kurum hafızasının korunmasında ve kurumsal işleyişin sürekliliğindeki önemi düşünülerek ilgili konudaki endişelerin giderilmesine dönük önlemlerin alınması, bu çerçevede yedekleme alanlarının, sunucu alanlarının ve güvenlik duvarlarının geliştirilmesi, teknolojik eskimeye karşı öykünme vb. uygulamaların düşünülmesi önemli görülmektedir.

Sistem hatasız bir şekilde işlemektedir sorusuna kararsızlarla birlikte olumsuz yanıt verenlerin oranının \%53'ün üzerinde olması sistemin işleyişine yönelik önemli bir sonuçtur. Bu çerçevede sistemin kendi içerisinde, işleyişinde ve/veya kullanımının etkinleştirilmesinde iyileştirmelerin yapılması gerekli görülmektedir. Özellikle teknik personelin sistem işleyişindeki hatalarla ilgili daha çok sıkıntılarının olduğu ortaya çıkmaktadır.

e-i̇çişleri kurumsal bilgi sisteminin yeni koşullara adaptasyonu konusunda genel olarak olumsuz bir tablo ortaya çıkmaktadır. e-İçişleri sistemi üzerinde farklı iş süreçlerinin birbiriyle entegre edilebilmesi konusunda kararsız yanıtlarının yüksekliği, katılımcıların bu koşullarla ilgili deneyim ve bilgilerinin yeterli olmaması ile açıklanabilir. Analizlere göre katılımcılar İçişleri Bakanlığında kullanılan e-içişleri kurumsal bilgi sisteminin genel olarak basılı ortamda yürütülen iş süreçlerine göre maliyeti ciddi oranda düşürdüğünü düşünmektedirler. Kurumda henüz tüm iş süreçleri bütünüyle elektronik ortama aktarılmadığı için kurumsal bilgi ve belge işlemlerinin maliyetinin yüksekliği konusunda kararsız yanıtların yüksek olduğu görülmektedir.

Bulgular genel olarak değerlendirildiğinde anket katılımcılarının İçişleri Bakanlığı içerisinde elektronik bilgi ve belge yönetimi sistemlerine yönelik öncelikle sistemin hızı ve etkinliği (tüm gruplar için yaklaşık \%80 civarında) ve sistemin kullanımına dönük hizmet içi eğitim gereksiniminin karşılanması konusunda sıkıntılar yaşadığı sonucu ortaya çıkmaktadır. İyileştirme gereksinimi olan alanlar arasında sistemin kurum içi ve dışı diğer sistemlerle entegrasyonu özellikle yöneticiler ve teknik personelin yaklaşık üçte ikisi tarafından dile getirilmektedir. Bu oranın diğer gruplarda \%50 civarında kalması söz konusu grupların konuya ilgileri ile açıklanabilir. Sistemin kullanımının kolaylaştırılması konusunda yöneticilerin diğer gruplardan farklı olarak \%70'in üzerinde iyileştirme istemesi bir diğer önemli sonuçtur. Yine sistemin güvenliği, teknik destek ve sistemin esnekliği konusunda tüm gruplar \%50'nin üzerinde iyileştirme ihtiyacı duymaktadır. Yönetici ve teknik personel grupları diğerlerinden daha yoğun olarak (\%60'ın üzerinde) sistem yetkilendirmelerinin yeniden düzenlenmesi gerektiği üzerinde durmaktadırlar. 
İçişleri Bakanlığı'nda e-devlet kapsamında kurumsal bilgi sistemleri uygulamalarına dönük koşulları ve sorunları ortaya koyan analiz sonuçlarına dayanarak aşağıdaki önerilere ulaşılmıştır:

$\diamond$ İçişleri Bakanlığında basııı ve elektronik bilgi ve belge yönetimi uygulamalarının kurum içerisinde koordinasyonu ve yürütülmesinden sorumlu bir birim oluşturulmalıdır. Bu birim İçişleri Bakanlığı Bilgi ve Belge Yönetimi Daire Başkanlığı şeklinde örgütlenmelidir. İlgili başkanlığında uzmanlık gerektiren çalışmalar Bilgi ve Belge Yönetimi Bölümlerinden mezun bilgi profesyonellerince yürütülmelidir.

$\diamond$ İçişleri Bakanlığında elektronik bilgi ve belge yönetimi uygulamalarının yürütüldüğü e-içişleri kurumsal bilgi sisteminin tek yönlü bilgi aktarma fonksiyonlarının geliştirilerek Web 2.0 araçlarının, e-posta ve diğer iletişim ortamlarının da sisteme entegre edilmesi; böylece iş süreçlerinde kullanılan örtük ya da yapılandırılmamış bilginin sistem üzerinde açık bilgiye dönüştürülmesine yönelik çalışmalar yapılmalıdır.

$\diamond$ Bilgi Teknolojileri ve Illetişim Kurumu tarafından geliştirilen ve henüz İçişleri Bakanlığı tarafından uygulamaya konulmamış KEP (Kayıtlı Elektronik Posta) çerçevesinde, Bakanlık içerisinde e-posta sisteminin yapılandırılması, böylece kanıt niteliğinde güvenli elektronik iletişimin sağlanması gerekmektedir.

$\diamond$ Içişleri Bakanlığında basılı bilgi kaynaklarının dijitalleştirilmesi sağlanmalı, sistemde yer almayan diğer elektronik kaynaklarla birlikte e-içişleri platformu geliştirilmelidir.

$\diamond$ Özellikle yönetici ve teknik personelin e-iççşleri üzerinden yürütülen resmi işlemlerin yasal dayanaklarının geliştirilmesine yönelik endişeleri göz önüne alınarak, yasal düzenlemelerde elektronik uygulamaların çerçevesi daha net çizilmeli, personelin de konuya ilişkin farkındalığının artırılması sağlanmalıdır.

$\checkmark$ Elektronik sistemlerde aranılan bilgi ve belgelere erişim konusunda yaşanan sıkıntıların giderilmesi üzerine, TS 13298 standardında yer alan üstveri alanları da göz önüne alınarak e-iç̧işleri veri tanımlama sistemi geliştirilmelidir.

$\diamond$ e-içişlerinin en olumsuz koşulları arasında değerlendirilen e-iç̧işleri kurumsal bilgi sisteminde yer alan bilgi ve belge kaynaklarının güvenliğine, bütünlüğü bozulmadan uzun süre arşivlenmesine dönük koşullar iyileştirilmelidir. Bu çerçevede ISO 27001 ve TS 13298 standartlarının öngördüğü uygulamalar gerçekleştirilmeli, güvenlik duvarları, gerektiğinde bulut yapısında yedekleme ortamları geliştirilmeli, teknolojik eskimeye karşı öykünme vb. uygulamalar düşünülmeli, konu üzerine uzman kişi ve kuruluşlardan teknik destek alınmalıdır.

$\diamond$ Içişleri Bakanlığında kurum içi iş süreçleri bütünüyle elektronik ortama aktarımasına karşın anket verilerinde de yer alan e-imzaya güvensizlikten ve yaşanan aksaklıklardan dolayı bazı birimlerde işlemlerin basılı ortama da alınması uygulamasından vazgeçilmelidir. Bu çerçevede sistem üzerinde e-imza kullanırken zaman zaman yaşanan sistem hatalarının da giderilmesi gerekmektedir. 
$\diamond$ Sistem üzerinde görev tanımları ve iş süreçleri ile buna bağlı yetkilendirmeler sadece kurum hiyerarşisi değil, yürütülen iş ve işlemlerle bu işlemlerde sorumlu personel göz önüne alınarak yeniden yapılandırılmalıdır.

$\diamond$ Kullanıcı beklentileri çerçevesinde e-içişleri sistemi içerisinde aranılan bilgi ya da uygulamaya daha rahat erişim için web sayfası kullanılabilirlikilkeleri ve bilgi mimarisi çerçevesinde yeniden tasarlanmalı, sayfaların açılış hızında yaşanan sıkıntılar da göz önüne alınarak sistemin teknik altyapısının geliştirilmesi gerekmektedir.

$\diamond$ Yapılan analizlerde ortaya çıkan lektronik belge yönetimi sistemi ve özelde e-İçişlerinin özellikleri ve kullanımı konusunda, personelin hizmet içi eğitim eksikliklerinin giderilmesine dönük Bilgi ve Belge Yönetimi Bölümlerinden destek alınarak düzenli hizmet içi eğitim programlarının başlatılması gerekmektedir.

$\diamond$ Yapılan analizlerde ortaya çıkan sistemin kullanımı ve yaşanan aksaklıkların giderilmesine yönelik teknik desteğin artırılması, sistem üzerinde yardım fonksiyonlarının geliştirilmesi gerekmektedir. Birim proje sorumlusu, bilgi işlem ve teknik personele uzanan zincirinin ortadan kaldırılarak, doğrudan teknik desteğe ulaşılmasını sağlayacak; sistem üzerinde anlık mesajlaşma ya da görüşme olanakları yaratılmalıdır.

Gerçekleştirilen çalışmanın benzerlerinin kamu ve özel sektörde yer alan diğer kurumlarda tekrarlanmasının, ortak standartlar ve uygulama modelleri ile birlikte kurumsal gereksinimler çerçevesinde elektronik belge yönetimi uygulamalarının geliştirilmesi açısından önemli görülmektedir.

\section{Kaynakça}

Azad, A. (2008). Implementing electronic document and record management systems. Boca Raton: Auerbach Publications. 12 Kasım 2012 tarihinde http://www.crcnetbase.com/doi/ pdf/10.1201/9780849380600.fmatt adresinden erişildi.

Barutçugil, ì. (2002). Bilgi yönetimi. İstanbul: Kariyer Yayıncılık.

Baş, T. (2010). Anket: Anket nasıl hazırlanır, anket nasıl uygulanır, anket nasıl değerlendirilir. Ankara: Seçkin.

Başa, Ş. (2012). e-Devlet çalışmalarına bir örnek. "e-içişleri projesi". Sosyo Ekonomi, 2012(1), 223-248.

Cimtech Ltd. (2009). Managing information and documents: The definitive guide. Birleşik Krallık: Cimtech Innovation Centre.

Delikurt, A. (2007). Türkiye' de e-devlet ve elektronik dönüşüm süreci: Sanayi.net uygulaması Yayınlanmamış yüksek lisans tezi, Gazi Üniversitesi, Ankara.

Deloitte Research (2000). At the dawn of e-government: The citizen as customer. 7 Eylül 2012 tarihinde http://www.egov.vic.gov.au/pdfs/e-government.pdf adresinden erişildi.

Elektronik İmza Kanunu. (2004). T.C. Resmi Gazete, Sayı: 25355, 23 Ocak 2004.

Fedorowicz, J., Gogan, J. L. ve Culnan, M. J. (2010). Barriers to interorganizational information sharing in e- government: A stakeholder analysis. The Information Society: An International Journal, 26(5), 315-329. 
Herrera-Viedma, E. ve Peis, E. (2003). Evaluating the informative quality of documents in SGML format from judgements by means of fuzzy linguistic techniques based on computing withwords. Information Processing and Management, 39, 233-249.

Horan, T. ve Abhichandani, T. (2006) Assessing user satisfaction of e-government services: Development and testing of quality-in-use satisfaction with advanced traveler information systems (ATIS). Journal of information technology management, XVII(4), 33-44.

İçişleri Bakanlığı Bilgi İşlem Dairesi Başkanlığı (2012). Yardım masası dokümanları.10 Şubat 2012 tarihinde www.e-icisleri.gov.tr adresinden erişildi.

Kampffmeyer, U. (2006). ECM-enterprise content management. Project Consult: Hamburg. 10 Aralık 2012 ftp://ftp.software.ibm.com/software/emea/de/db2/ 20070808_ECM_White-Paper_kff_ IBM_Endversion.pdf adresinden erişildi.

Külcü, Ö. (2010). Belge yönetiminde yeni fırsatlar: Dijitalleştirme ve içerik yönetimi uygulamaları. Bilgi Dünyası, 11(2), 290-331.

Mokhtar, U. A. ve Yusof, Z. M. (2009). Electronic records management in the Malaysian public sector: The existence of policy. Records Management Journal, 19(3), 231-244.

NHS National Library for Health (2005). ABC of knowledge management. 9 Ekim 2012 tarihinde http://www.fao.org/fileadmin/user_upload/knowledge/docs/ABC_of_KM.pdf adresinden erişildi.

Özata, M. ve Sevinç, İ. (2010). Türk kamu yönetiminde bilgi sistemleri ve e- dönüşüm. Konya: Eğitim Kitapevi.

Özbek, M. (2007). E-devlet ve Türkiye uygulamaları kapsamında "Vedop" projesi. Yayınlanmamış yüksek lisans tezi, Gaziosmanpaşa Üniversitesi, Tokat.

Özdamar, K. (2004). Paket programlar ile istatistiksel veri analizi 1. Eskişehir: Pegem.

Özdemirci, F. (2008). Üniversiteler için belge yönetimi ve arşiv sistemi (BEYAS)geliştirme ve uygulama projesi: Bir işbirliği örneği. Balkan Ülkeleri Kütüphaneler Arası Bilgi-Belge Yönetimi ve İşbirliği Sempozyumu Bildirileri içinde (s. 225-235). Edirne: Trakya Üniversitesi.

Sprehe, J. T. (2005). The positive benefits of electronic records management in the context of enterprise content management. Government Information Quarterly, 22(2), 297-303.

Verdegem, P. ve Verleye, G. (2009). User-centered e-government in practise: Acomprehensive model for measuring user satisfaction. Government Information Quarterly, 26(3), 487-497.

Worldbank (2012).ADefinition ofe-Government.10 Aralık2012 tarihinde http://web.worldbank.org/ WBSITE/EXTERNAL/TOPICS/EXTINFORMATIONANDCOMMUNICATIONANDTECHNOLOGIES/ EXTEGOVERNMENT/0,,contentMDK:20507153 menuPK:702592 pagePK:148956 piPK:2166 18 theSite PK:702586,00.html adresinden erişildi.

Yao, L. J., Kam, T. H. Y. ve Chan, S. H. (2007). Knowledge sharing in Asian public administration sector: The case of Hong Kong. Journal of Enterprise Information Management, 20(1), 51-69.

Yıldırım, M. (2010). Kamu yönetiminde bilgi yönetiminin gerekliliği üzerine bir inceleme. Uluslararası Insan Bilimleri Dergisi, 7(1), 1311-1334.

Yıldız, A. K. (2005). Kurumsal bilginin stratejik planlamadaki rolü. Yayımlanmamış yüksek lisans tezi, Marmara Üniversitesi, İstanbul 